\title{
Conceptual and Historical Reflections on Chance (and Related Concepts)
}

\author{
Christoph H. Lüthy and Carla Rita Palmerino
}

\begin{abstract}
In everyday language, the use of such words as "chance," "coincidence," "luck," "fortune" or "randomness" strongly overlap. In fact, in some languages, such as German, they coincide in one word (Zufall). In others, there is a clear separation between chance events with positive connotations (e.g., "luck," "fortune") and those with bad ones (e.g., "accident," "hazard"). In this essay, we try to sketch the main lines of development of several of these concepts from the ancient Greeks up to modern times, or more precisely, from Democritus and Aristotle up to the world of quantum mechanics. Three elements emerge with particular force. First, "chance," "fortune," "randomness," etc. are in some instances invoked as explanations of events, but in others designate events that occur without an explanations. Second, the meaning of these terms only becomes clear when one understands which alternatives they exclude. Finally, it is conspicuous to see how, after a rigid exclusion of "chance" or "randomness" from the domain of scientific explanation in the early modern period, they were restored to full glory in nineteenth- and twentieth-century biology and physics.
\end{abstract}

There exists a cluster of words with which we designate events that in some way or another surprise us, either because we didn't expect them, or because they are out of the ordinary, or because they seem inexplicable. "Chance," "coincidence," "randomness," and "luck" are words that belong to this category of surprise. Sure enough, each of them has more technical meanings, particularly when used in

We would like to thank Ellen van Wolde, Klaas Landsman, Jos Uffink and Frederik Bakker for their comments on earlier drafts of this chapter. The section on modern physics is based on a text provided by Klaas Landsman, which we have slightly adjusted.

C.H. Lüthy $(\varangle) \cdot$ C.R. Palmerino

Center for the History of Philosophy and Science, Faculty of Philosophy,

Theology and Religious Studies, Radboud University, Nijmegen, The Netherlands

e-mail: c.luethy@ftr.ru.nl; c.palmerino@ftr.ru.nl

(C) The Author(s) 2016

K. Landsman and E. van Wolde (eds.), The Challenge of Chance,

The Frontiers Collection, DOI 10.1007/978-3-319-26300-7_2 
specific scientific and non-scientific contexts; take, for example, a mathematically precise notion such as Martin-Löf randomness. ${ }^{1}$ But as far as everyday language is concerned, our terms strongly overlap. Phrases such as "I met him by chance," "this was an extraordinary coincidence," "I was randomly chosen," or "I was lucky enough to escape" all gesture at the fact that we couldn't have predicted what in fact happened to us or to someone else.

All of these terms are popular, and some are used with great frequency. And yet, it is very difficult to say what exactly they mean. It is impossible to develop either a coherent theory or a single narrative around them. They are simply too soft conceptually, too imprecise, and in fact even contradictory. Most people would probably agree with the Enlightenment philosopher David Hume that "chance, when strictly examined, is a mere negative word, and means not any real power which has anywhere a being in nature." (Hume 1748, Ch. 8.1).

One important reason why it is impossible to give a coherent account of this negative word and of its siblings is that they are used both to offer an explanation and to signal the lack of an explanation! Two examples will suffice to demonstrate this. In the sentence, "She didn't know the game, and that she won was sheer luck," the word "luck" signals the absence of a good explanation (such as routine or skill) to account for the fact that someone won at a game. The logic is quite different in the sentence, "through this lucky coincidence, she managed to win the elections." Here, the "lucky coincidence" offers an abbreviated explanation. The "coincidence" might refer to the fact that Harry, the obvious candidate, had suffered a stroke, and Lucy, his opponent, had on the same day been imprisoned, so that Theodora, whose ambitions had previously seemed implausible, could now win the elections. While in the first sentence the expression "sheer luck" signals the absence of a convincing causal explanation, in the second the expression "lucky coincidence" provides the explanation, while obviously also indicating its unforeseen nature.

Depending on the context, "chance," "coincidence," "randomness," or "luck" do not only indicate the presence or absence of a recognizable causal logic, but they also indicate unknown probabilities, which might or might not be calculable. "Chances are that you won't make it," or "If you are lucky, you might still catch that train," are phrases which imply an embryonic form of probabilistic reasoning of the type "what are the odds that $x$ happens?"

Explanation, lack thereof, or intuited probabilities: it is in this ill-defined, swampy area that the terms we are examining here are located. As a consequence, Madam Fortune, the mythological personification that rules over these swamps, will necessarily also assume multiple roles. At one extreme, she will manifest herself as a divine figure that determines our fate; reference to her will in that case provide a coherent answer for explaining why things that for us had been unpredictable had nevertheless happened. At the other extreme, she is as helplessly exposed to

\footnotetext{
${ }^{1}$ On different mathematical definitions of randomness, see Sebastiaan Terwijn's chapter in this book.
} 
circumstances as we are. A fickle woman placed on the allegorizing weather vane who is swept about by the winds, she is herself the object of unpredictable influences. Explaining an event through fortune characterized in the latter way amounts to empty prattle, as it merely moves unpredictability to a different level.

Despite the elusive and contradictory explanatory value of this cluster of words, there are interesting things than can be said about them. In our first section, we will first try an etymological approach. There, we will encounter a strong presence of falling dice as well as of lots, straws and other literally "aleatoric" objects of gaming and decision making, including the emblematic Wheel of Fortune. But we will also witness a strong and unresolved tension between viewing fortune and chance as a final (possibly divine) explanation for unexpected occurrences, and that of depicting them as merely a higher level of unpredictable randomness.

Our main approach is, however, historical. We will in some detail survey a number of key moments in the history of scientific (or natural philosophical) thought, from the divine fate of Greek tragedy and the chance swerve of Epicurean atoms through the deterministic machine world à la Descartes up to the reintroduction of chance and randomness in scientific theories as diverse as evolutionary theory and quantum physics. In this section, we will see that, as a general rule, philosophy and science have repeatedly tried to drive chance and coincidence out of their domain - unless they could stand for a precise type of causal factor that was required for a specific type of physical explanation - but that, time and again, chance entered anew through the back door.

We will end by concluding that our terms are best understood ex negativo. In order to understand what scientists or philosophers of past and present ages mean when they attribute something to chance, coincidence, randomness or luck, it is indispensable to understand what it is that they wish to exclude. Is it necessity, fate, determinism, causal knowledge, regularity, high probability, or something else? Given the obvious vagueness and contradictoriness of the connotations of our original set of words, it will come as no surprise to see that their contraries are just as ill-defined. Still, there is a strong heuristic advantage to this exercise. Being aware of what it is that we wish to exclude, we, the readers of this essay, will at least have some greater clarity of what it is that we implicitly wish to affirm with our underdetermined words.

\section{Etymological Prelude}

\subsection{Dice and Other Falling Objects}

We have opened this essay with the observation that "chance," "coincidence," "randomness," and "luck" may possess precise meanings in specific scientific and 
cultural circumstances, but that in everyday language, their meanings overlap. ${ }^{2}$ Let us now add that this overlap is much greater in one language than in another. A particularly striking case is German (and the same is true for Dutch), where the word "Zufall" covers all four English terms: "eine zufällige Begegnung" is "a chance encounter"; "ein seltsamer Zufall" is translated as "a rare coincidence"; "ein zufälliger Passant" would be "a random passer-by"; and "ein Zufallstreffer" could be translated as "piece of good luck." Now, Zufall, this all-encompassing German word, is an old but literal translation of the Latin accidens: "something that falls down" or "upon."

Cadere, the Latin verb for "to fall," stands in fact at the root of several of the words that we are investigating in these pages. To begin with, there is of course the Latin noun casus, "the fall," a word that can describe the falling of snow, but also everything else that literally "befalls" us, however improbable it may be. Casus is therefore also the Latin word for "chance," "coincidence," or "luck." In Italian, it has retained precisely that meaning: "Sei per caso in città domani?" is literally "Are you by chance in town tomorrow?" The English word "case," which barely hides its Latin origin, has lost most of the original significance of casus, although the adjective "casual" still retains some of it, as when we speak of a "casual meeting."

What "befalls" us can be pleasant or unpleasant. Whereas Zufall is neutral in that respect (an event can be a glücklicher or unglücklicher Zufall), the Latin accidens, of which Zufall is a translation, has in many languages assumed a predominantly negative connotation. While the adverb "accidentally" still means "by chance," the noun "accident" has clearly negative connotations. The phrase, "It was an accident," would nowadays never be used with reference to a "fortune" won at the lottery, but most certainly so as to explain why the window is broken. The same negative connotation of "accident" is found in French or Italian, while in German, the oddly inauspicious prefix un- in Unfall does the same trick. Significantly, the French word hazard, which ultimately seems to go back to an Arabic expression relating to the throwing of dice, has had the same double fate as "accident": while par hazard is emotionally neutral, simply meaning "by chance," the English "hazard" and "hazardous" - as in "hazardous waste" - are negatively charged.

But the element of "falling" is even more pervasive than that. Just like "case," the English word "chance" also derives in the last instance from the Latin verb cadere. It has however made a certain detour, deriving ultimately from cadentia, "the ways in which the dice fall," which later became chéance in old French. Just like "hazard," which — as mentioned before - may derive from an Arabic word that also refers to the unpredictable way in which the dice fall, "chance" eventually came to designate whatever happens without us being able to determine it. Seen in

\footnotetext{
${ }^{2}$ The following etymological paragraphs were written on the basis of the Oxford English Dictionary, 2nd ed. (1989), s.v.; Historisches Wörterbuch der Philosophie, voice "Zufall”; Duden. Deutsches Universalwörterbuch (2007), s.v.; the Online Etymological Dictionary, s.v.; as well as various Latin, Greek, French, German and Italian dictionaries.
} 
this light, Julius Caesar's famous pronouncement, "The die is cast" (alea iacta est), which announced his much thought-over decision to cross the Rubicon and start a civil war, would be an oddly inappropriate metaphor, given that Caesar's was everything but a random decision. But in fact, it appears that he spoke the phrase in Greek, citing a line from a comedy by Menander; the Greek phrase anerrhiphtho kubos should in fact be translated as alea iacta esto, "let the die be thrown," referring not to the decision taken, but instead to the uncertain outcome of the enterprise that was to follow from it (Lewis and Short 1879, s.v. alea).

The word "coincidence" derives from the Latin verb cadere in a more visible way. A "coincidence" takes place when things "fall" (cadere) "together" (co[n]-) and "upon" (-in) something. The word is not ancient Latin, but medieval, and it seems to have first been used in astrology, where coincidentia referred to the joint influence of multiple planets. This genealogy gives us an indication of a basic difference between "chance" and "coincidence": the latter requires more than one thing to happen at the same time. In the sentence, "By chance, I was born into a rich family," you could not replace the first word by "by coincidence." Meeting your neighbour in a far-away vacation location, by contrast, certainly qualifies as a coincidence; after all, you both had to travel there in order for your paths to cross.

These various shades of "falling" are instructive. It is certainly noteworthy how many terms there are in English and other languages that express surprise at a certain event or "occasion" (yet another such word) in terms of a "fall." It is as if the casus, "chance" or Zufall always fell down from above, literally "out of the blue." The proverbial "stroke of luck" would therefore have to be represented by the gesture of a fast downward arm movement.

More indirectly, the same is true for other words, such as "luck," which-though related to Germanic words for happiness and fortune-seems to have entered English as a gambling term. Like "accident," it might originally have referred to the way in which the dice fall, although this time with a uniquely positive connotation. The "falling" of the casus has here been confined to the descent of circumscribed objects on the gambling table. Still, the downward direction has remained intact.

\subsection{Fortuna, Wheels and the Lottery}

Still related to gambling, but involving quite a different type of movement, is the Wheel of Fortune. In late Antiquity and medieval times, this wheel was the constant attribute of the goddess Fortuna, who was spinning it (either blindfolded, or else maliciously watching) as men and women were literally "rising to fortune" or descending rapidly, "losing their fortune." Whether blind or seeing, Madam Fortune was a puppeteer, we mortals were her puppets. But then, as we have mentioned earlier, she was also regularly depicted in a passive role, herself the victim of unpredictable change. A particularly striking depiction of this latter figure was given by the Roman tragedian Pacuvius, who sketched the following portrait: 
"Philosophers proffer the view that Fortune is insane and blind and stupid, /And they teach that she stands on a round, spherical rock: /They assert that, where chance (fors) pushes that rock, there Fortuna will fall." ${ }^{3}$ Once one realizes that the word fors, "chance," stands at the root of the name of the goddess Fortuna, one begins to stare down the mirror cabinet of an infinite regress: we get a situation in which we humans rise and fall, tied to the Wheel of Fortune, while the goddess herself falls from the ball on which she stands, pushed in turn by "chance" (of which one had mistakenly expected her to be the ruler and embodiment).

In his demolition of the pantheon of pagan deities, Saint Augustine in The City of God directs his glance also at Fortuna (Book IV, Ch. 18). Why, he asks, is Fortuna traditionally associated with "felicity" - the Romans had initially endowed her with a cornucopia, and had thus viewed her as an exclusively positive figure-although we know that one can also have "bad fortune?" Such an identification doesn't make any sense, according to Augustine. Further, why should Fortuna be considered a goddess, if she can also bring about bad things? Plato tells us clearly that it is the essence of gods to be good; "how, then, is the goddess Fortuna sometimes good and sometimes bad? Is it perhaps that when she is bad, she is not a goddess, but is suddenly transformed into a malignant demon?" (Augustine 1998, 164). And finally, what should we make of the fact that the name of the goddess is also derived from the word fortuito, that is, "by accident?" How can she be a goddess if what we ascribe to her happened accidentally? In a few lines, Augustine exposes all the contradictions that reside in the concept of a deified principle of randomness, and all the inner tensions between a principle that should account at the same time for luck, happiness, destiny, the vicissitudes of life and personal success.

It is surprising to see that despite Saint Augustine's debunking, Fortuna was highly popular in the Middle Ages. In the meantime, however, her cornucopia had definitely disappeared for the wheel (Vogt 2011). Fortuna had changed from the positive figure ridiculed by Augustine into a highly ambivalent one. This may come as a surprise, as the idea of the random rise and fall of people (and peoples) is of course profoundly un-Christian, as it contradicts the notion of providence. And yet, it survived, and in fact thrived, in the hands of medieval Christianity. Dante Alighieri eulogizes Fortuna as nothing less than the first creature of God, who rules over the world and makes it spin about according to her occult whims, which are ominously invisible "like the serpent in the grass." With respect to God and to humans, she is "general servant and leader," respectively (Divina Commedia, "Inferno," VII.78-84).

It has been argued that the popularity of Fortuna in the Middle Ages is due to the late Roman author Boethius, in whose Consolation of Philosophy Fortuna makes a striking appearance, declaring:

\footnotetext{
${ }^{3}$ Pacuvius, ed. O. Ribbeck (1897), vol. 1, vv. 365-375: "Fortunam insanam esse et caecam et brutam perhibent philosophi,/ Saxoque instare in globoso praedicant volubili:/ Id quo saxum inpulerit fors,/ eo cadere Fortunam autumant."
} 
This is my art, this the game I never cease to play. I turn the wheel that spins. I delight to see the high come down and the low ascend. Mount up, if you wish, but only on condition that you will not think it a hardship to come down when the rules of my game [ratio ludicri mei] require it (Boethius 1897, II.2p, trans. modified).

Curiously, while Fortuna goes about her pagan business of causing the rise and fall of people, she seems (at least in this passage), to give us the choice between participating in the "ludicrous game" or abstaining from it. In fact, she quickly recalls to her listener the brutal fall of the Lydian king Croesus. The theme of the fall of kings - and here we are back with the previous etymology, of the casus and the "accident" - was popular throughout the Middle Ages. The Carmina Burana warns the powerful of the inevitable turning of the wheel: "too high up/ sits the king at the peak/ let him beware of ruin!"4 In fact, a particularly popular image was that of four kings attached to a wheel, with one ascending (regnabo, "I will rule"), one on top (regno, "I rule"), one dethroned and descending (regnavi, "I have ruled"), and one at the bottom (sum sine regno, "I have no kingdom").

However, Boethius' Fortuna does not only seem to give us the choice between taking a ride on her wheel or leaving it, but Boethius himself, in Stoic fashion, recommends that we should seek our tranquillity irrespective of the vicissitudes afflicting our personal lives. Moreover, he suggests that there is a higher, maybe Platonic or else providentially Christian level at which it all makes sense. It has in fact been suggested that the ubiquitous medieval representations of Fortuna should be interpreted through the influence of Boethius (Vollmer 2009). The advantage of this explanation is that it helps us explain how it was possible that the pagan Wheel of Fortune could end up defining the shape and iconographical program of cathedral roses and church interiors (see Fig. 1).

An entirely demythologized, contemporary version of the Wheel of Fortune is the lottery wheel, which is inscribed by numbers corresponding to lottery tickets and a pointer pointing to the rim. The wheel is spun, and when it comes to a standstill, the ticket carrying the number corresponding to the number indicated by the pointer wins. With this device, we have arrived at our last set of terms. Originally, the "lot" was any object - a piece of straw, a chip of wood with a name on it, or, as in so many earlier examples, a die-that was used to determine someone's share, for example in an inheritance. A "lot" of land (and even the trivial "parking lot") still refer to that process of "random allotment" as does the phrase, "what falls to a person by lot." But when we recall the figure of Fortuna spinning her wheel, or deciding the outcome of the draw or the casting of dice, we will understand how "lot" and "lottery" could also come to refer to any "(ill-)fortune" that life has in store for us. The village lottery may assign a lot of land to us; the phrase "It was my lot to be born poor" refers instead to a lottery in which I was not able to buy even my own ticket.

\footnotetext{
${ }^{4}$ Carmina burana (1974), song 16: "nimis exaltatus / rex sedet in vertice - / caveat ruinam!”.
} 


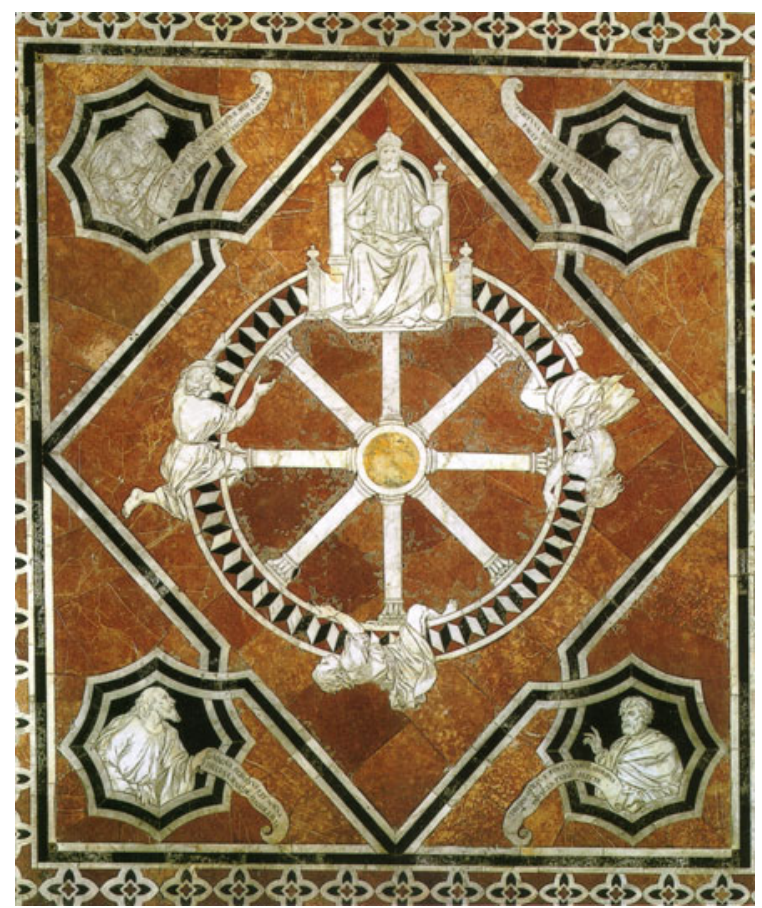

Fig. 1 Fortuna (1372) depicted on the floor of the Cathedral of Siena. Is the ruler on his throne (regno) about to fall (regnavi), or is he rather, solidly enthroned, supervising the ascent and descent of the other figures? Strikingly enough, the four philosophers in the corners are all pagan: Euripides ("I have told you, son, to seek fortune through labours," from Elektra); Seneca ("A great fortune is a great slavery," from De consolatione); Aristotle ("Great fortune makes men more petulant," from the Politics); and Epictetus ("Glory not in the gifts of fortune, but in the goods of the souls," from the Enchiridion). Their advise has no providential, Christian, or eschatological overtones, but combines classical prudentialism with the topos of virtus vincit fortunam ("virtue/determination wins over fortune"): don't seek fortune, but if you do, seek it through hard labour; but be beware that it will negatively affect your character; and anyway, "it's what's inside that counts."

\subsection{Randomness and Reckoning with Fortune}

With the "randomness" of the lottery's decision-making process, we have arrived at the last word in our etymological survey. There was once an Old Frankish word, *rant, cognate to the English "running," which eventually became randir, "to run fast," in Old French, as well as randon, meaning "rush" and "disorder." From the French, it migrated to English, where it became "at random," which originally meant, "at great speed" and hence "without order" and "haphazardly." By 1650, it had acquired one of its current meanings, by referring to events that took place "without definite aim or purpose." Originally, it was actor-bound: an individual was said to act "randomly," that is, without purpose, for example by pointing at 
someone while blindfolded. The use of the word as an adjective, as well as the identification of "chance events" with "random events," seem to be of more recent date. Of even more recent date are the mathematical theories of randomness, which are an extension of classical probability theory, or the quantum-mechanical randomizers.

These recent developments are interesting from a philosophical perspective. For once one equates randomness with chance, and once chance becomes calculable, as it did over the past three and a half centuries thanks to the mathematical determination of probability, one somehow also domesticates chance, randomness, and possibly even one's lot. Looking at a set of global statistics, one may now state: "The odds were high that I would be born poor." In Boethius' Consolation (II.3p), we have Fortune asking defiantly: "Do you wish to count out the score with Fortune?" (Visne igitur cum fortuna calculum ponere?). Through the mathematization of probability, we are attempting to do just that: "Reckon with fortune." As several chapters in this book document, this reckoning has taken on high forms of abstraction in various disciplines.

And yet, despite all domestication of chance, luck, fortune, coincidence and randomness in the specialized disciplines, the old meanings have not disappeared. Fortuna may no longer be a deity, but the surprise, the rage, the joy, and the bewilderment that something particular happened to us, of all people, that it had to happen just then and there, has not vanished. Nor have most of the terms and expressions that the Greeks, the Romans and our medieval ancestors used.

Did, then, our etymological exercise tell us anything useful? If we had hoped for a conceptual convergence between the words investigated here, then we were (predictably) deluded. Between the goddess who spins the wheel, the blind and hasty rush forward, life's lottery, the ubiquitous falling of dice, and all other unpredictable coincidences and accidents, there is little that amounts to any overarching notion of how we must "account" for the unforeseen events in life, nature or history. The divergent uses of the words we investigated, and even of single words, is however illuminating. To remind ourselves of the most dramatically ambivalent word, "fortune," we have seen that Fortuna could appear as a goddess of "good fortune," with her cornucopia at the ready; she could be a (still personified) semi-independent cosmic force governing over chance, coincidence and randomness; she could be a way of life that one could choose to follow or else ignore; but "fortune" could also be the well-deserved result of hard work, the danger being, however, that it might corrupt our character.

To be aware of the internal tensions between the various sub-meanings of the words seems to us an important step towards a comprehension of what these words can possibly be intended to achieve. But their full complexity only becomes apparent once one places them into the philosophical and scientific context in which their role in the causal nexus of things was examined. This is what needs to be done next. 


\section{History}

\subsection{Greek Origins}

Let us therefore turn to an examination of a number of key moments in the intellectual-that is: philosophical and scientific-evolution that our words have undergone, and the explanatory (or causal) role that was attributed or denied to them. We must start with ancient Greece, because it is there that our current terminology takes its origin. It is also there that we find, for the first time in Western intellectual history, a debate about the status of unexpected events and the way we must deal with them conceptually.

We have begun our essay with the element of surprise that characterizes the various terms in question. In ancient Greece, the word that designated an unexpected turn of events in a human life or in the observed natural world was tuchê. In comedies, tragedies and in works of historiography, tuchê is invoked to designate such unforeseen events, which may derive from the gods or from mere fortune [tas tôn theôn tuchaskai to chreôn (Euripides, Hercules Furens 309-11)]. If from the gods, tuche is of course providential, which means that what to us may seem "by chance," is instead "by necessity" or "will" at a higher, divine, level. The existence of such a two-tiered logic explains why Sophocles can speak, in what at first looks like an oxymoron, of "necessary chance" (anankaia tuchê, Ajax 485, 803), a combination of words that in other texts is rendered as "fate" (moira, potmos). But while the older tragedians Aeschylus and Sophocles seem to have equated tuchê with fate, their younger colleague Euripides was less inclined to attribute all unforeseen events to a providential plan (Dudley 2012, 137). In Hecuba 488-491, a certain Talthybius wonders, for example, whether it is the gods or rather chance (tuchê) that rule over human affairs, thereby clearly separating the two (Lawrence 2013).

\subsection{Aristotle}

Distinctions and reflections that in literary works were merely adumbrated were made most fully explicit in that potent thinker whom Dante called "the master of those who know," namely Aristotle, whose philosophical and scientific teachings were to define Western university education until the end of the seventeenth century. In various of his works, we find Aristotle reflecting on the possible role that chance might play in the natural world and in human affairs. Always an acute analyst of terminology, he carefully examined various types of chance, distinguishing between tuche, on the one hand, and such related concepts as to automaton (a type of spontaneity), and eutuchia (which might be translated as "good fortune").

Aristotle's most extensive treatment of chance is found in book 2 of his Physics. As is often the case, Aristotle starts his analysis with an historical excursus. 
Previous philosophers have failed to give an account of chance, he tells us, which is all the more surprising as some of them have attributed to chance a fundamental role in their physical systems (Physics 195b30-196b9). Aristotle here thinks of Empedocles' cosmogony, which relies on air that moves upwards by chance and speaks of the haphazard origin of limbs of animals; but he thinks even more clearly of Democritus, who maintains that "the cosmic order came by chance [...], whereas neither animals nor plants are, or come to be, by chance, but are all caused by Nature or Mind or what else." Aristotle laughs this idea out of court, arguing thus:

But if this really were so, that very fact ought to give us pause and convince us that the matter needs investigation. For, in addition to the inherently paradoxical nature of such an assertion, we may note that it is exactly in the movements of the heavenly bodies that we never observe what we call casual or accidental variations, whereas in all that these people tell us is exempt from chance such things are common. Of course it ought to be just the other way (Aristotle 1957, 196a25-196b5).

Famously, Aristotle inverts the order: for him, "regular and customary successions," such as those observed in the heavenly motions, must happen by necessity (ex anankês), whereas the terrestrial realm is defined by a great degree of randomness. Regular necessity is observed throughout the superlunary sphere, where the sun, the planets and the stars are located and which is defined by one single element, ether, and by constant, circular movements. By contrast, in the sublunary sphere, where the four elements constantly mix and unmix, objects continuously come about and perish again. Here, where we find irregularity and surprising events, we may truly speak of products of chance (hê tuchê kai to automaton). Let us here remember that this stark Aristotelian opposition between two cosmological domains, each with its distinct ontological status and its own set of physical laws, was to break down only in the aftermath of Copernicus and Kepler in the course of the seventeenth century.

Aristotle admits that, in our sublunary domain of permanent change, "what we call luck or chance corresponds to some reality" (Aristotle 1957, 196b15-17). At the same time, he rejects the suggestion that tuche should be viewed as a specific type of causality. Instead, chance events should be regarded as accidental, that is to say, concomitant effects of a definite cause: "Tuchê," Aristotle writes in his Physics, "is a cause only accidentally (kata symbebêkos)" (ibid., 197a14f). But what does it mean to be an accidental cause? In his Metaphysics, Aristotle defines "accident" as that which happens "neither necessarily, nor usually," adding that there is "no definite cause for an accident, but only a chance, i.e., indefinite cause (aoriston)" (Aristotle 1933, 1025a15). If a man goes to the market and "accidentally" meets his debtor, "the reason of his meeting him was that the wanted to go marketing; and so too in all other cases when we allege chance as the cause, there is always some other cause to be found" (Aristotle 1957, 196a1-8). Here, then, we have the typical surprise moment mentioned in our introduction. The man may have wanted to buy cheese and vegetables, but, "as it happened," he encountered his debtor. That the verb sumbainô, of which symbebêkos ("accident") is the past participle, literally means "to walk together," is most suitable for this specific Aristotelian example, as 
it provides a quite visual model for what we have earlier defined as a "coincidence": two men walking, each steered by his own intentions, to the market, but "accidentally" ending up in each other's company.

In order to make sense of Aristotle's distinctions, one has to remember that his entire universe, and the causality that is active in it, is everywhere purposeful and goal-driven, so that the explanations he offers tend to be teleological. In such a universe, tuchê is an "accident" in the sense that it designates those events that eschew all purposes. In the natural world, a typical class of "accidents" is constituted by monstrous births, which also include female babies and which may be regarded as "failures of purpose in Nature" (Aristotle 1957, 199b4), in the sense that accidental factors hindered the natural development of the seed. ${ }^{5}$

Being "characteristic of the perishable things of the earth" (Aristotle 1937, 641b15), chance manifests itself above all in the domains of biology and of human action. Sometimes, Aristotle in fact wishes to limit the scope of tuchê even further, restricting it to rational behaviour. "Neither inanimate things nor brute beasts nor infants can ever accomplish anything by tuchê, since they exercise no deliberate choice." By contrast, the larger category, automaton, describes cases in which "any causal agency incidentally produces a significant result outside its aim" (Aristotle 1957, 197b19-23). Spontaneous generation, in which the presence of warmth can bring about worms or insects in a heap of dung or a warm puddle, is a case in which non-rational agents bring about a meaningful product by a sheer concurrence of circumstances.

If taken in this restrictive meaning, tuchê becomes the object of ethical reflection. In his Eudemian Ethics, when discussing the cause and the ethical bearing of good luck (eutuchia), Aristotle formulates an interesting paradox: we tend to call those persons "fortunate" (eutuchês) who "without the aid of reason are usually successful" (Aristotle 1935, 1247b27-28). This is however in contradiction with the accepted definition of chance or fortune (tuchê), which implies that something happens neither always nor even regularly (ibid., 1247a31-35). In order to resolve this paradox, Aristotle distinguishes between two types of fortune. The first is due to the aid of a god, whereas the second type of fortune is that of persons who are successful because they instinctively choose for the right course of action. Both sorts of good fortune are "irrational," in the sense that they are not obtained through our conscious choice, but the first is continuous, whereas the second is incidental (ibid., 1248b5-10).

What Aristotle's sundry ethical, physical and biological reflections on chance have in common is an emphasis on the inherent lack of reflection, premeditation or, in short, rationality. Good luck (eutuchia), chance (tuchê) and spontaneity (automaton) are all paralogos, unaccountable by reason, either because there is no purpose

\footnotetext{
${ }^{5}$ Both in Physics and in the Generation of Animals, monsters are regarded as "chance substances"; see Dudley 2012, 171, 175.
} 
involved (as in the case of worms being spontaneously generated in a heap of dung), or because the result of an action was not intended (as the man meeting his debtor on the market square) (Physics, 197a10, 18-20 and Eudemian Ethics, 127a33-38). It is precisely their undirected, irregular and contingent nature that also renders chance events "unscientific." For Aristotle, "science" (episteme) designates a psychological state in which the mind possesses knowledge with regard to the causes of an event. In the case of accidental events, the cause is however "unrecognizable," "indefinite" and "irrational" (paralogos) (Physics, 197a8-35).

\subsection{The Ancient Atomists}

So much for Aristotle himself. Let us however return to the atomists he criticized for what he took to be a misguided cosmogony and a misleading causal theory. We recall from above that Aristotle ridiculed Democritus specifically for suggesting that the cosmic order was the product of chance. Interestingly, the doxographer Diogenes Laertius provides a different version of Democritus' convictions, ascribing to him the view that "everything happens according to necessity; for the cause of the coming-into-being of all things is the whirl [that is, the atomic vortex which gave origin to the world], which he calls necessity" (Laertius 1925, IX, 45). Similarly, the only extant fragment of Leucippus, who may have been the inventor of the concept of atom, reads: "Nothing exists at random (matên), but everything for a reason $(\log o s)$ and by necessity (anankê)" (Kirk et al. 1983, 420).

Why should Aristotle then have attributed to Democritus the view that the world came about by chance (apo tautomatou)? According to Edmunds' influential interpretation, he did so to stress the purposeless character of the atomistic cosmos (Edmunds 1972). ${ }^{6}$ We recall from above that according to Aristotle's own definition, automaton "means an occurrence that is in itself to no purpose" (Physics 197b25-30). In other words, what to Leucippus and Democritus was "necessary" and hence the contrary of "chance" would for Aristotle have been its very opposite, namely a blind and therefore unguided and random event. Put differently, what was a deterministic "necessity" to one philosopher was mere "chance" to the other. This is a typical example for the phenomenon that will be discussed in our conclusion: the terms with which we are engaging in this chapter can only be understood if one knows the alternative terms they wish to rule out.

Indeed, as A. A. Long has perceptively pointed out, chance (tuchê) is incompatible with necessity (anankê) only if the former is taken to indicate events that are the result of sheer contingency and indeterminacy (Long 1977, 67-68). This observation takes us to Epicurus, the first philosopher to have explicitly introduced

\footnotetext{
${ }^{6} \mathrm{~A}$ similar point is made by Cherniss (1935), 248-49, and Long (1977), 67.
} 
an element of contingency and indeterminacy into the universe. Epicurus in fact criticized previous natural philosophers, including the atomists he followed in his physics, for attributing the origin of the cosmos to necessity and for making man the slave of destiny (Epicurus 1931, Letter to Pythocles, 89-90; Letter to Menoeceus, $131,133,134)$. He himself hoped to avoid absolute determinism by postulating a parenklisis, a spontaneous swerve that atoms suddenly perform, deviating from their rectilinear parallel paths and intermingling as a consequence of these deviations. In his own rendition of Epicurus' theory, Lucretius explained how this swerve, which he called clinamen, was responsible for breaking "the bonds of fate and preventing one cause from following from another from infinity" (Lucretius 1924, 2.251).

According to Cicero, the main function of Epicurus' clinamen was that of introducing freedom into a universe that would otherwise be fully defined by necessity:

The reason why Epicurus brought in this theory was his fear lest, if the atom were always carried along by the natural and necessary force of gravity, we should have no freedom whatever, since the movement of the mind was controlled by the movement of the atom. The author of the atomic theory, Democritus, preferred to accept the view that all events are caused by necessity, rather than to deprive the atoms of their natural motions (Cicero 1941, On Fate, 23).

While Cicero pitted necessity against freedom, Epicurus himself distinguished between three concepts, namely "necessity," "chance" and "freedom":

With us lies the chief power in determining events, some of which happen by necessity and some by chance, and some are within our control; for while necessity cannot be called to account, (...) chance is inconstant, but that which is in our control is subject to no master, and to it are naturally attached praise and blame (Epicurus 1926, Letter to Menoeceus 133).

In other words, from the ethical point of view, we cannot be blamed for actions that are due to necessity or chance, as both types defy our control. Only those actions that we control are free. But are we in control of the swerves of the atoms in us? How convincing is Lucretius' statement-which incidentally corroborates Cicero's analysis of the raison d'être of the swerve - that "what keeps the mind itself from having necessity within it in all actions (...) is the minute swerving of the first beginnings at no fixed place and at no fixed time?" (Lucretius 1947, 2: 288293). In fact, the debate on whether or not the swerve, which might look like the epitome of randomness, was really meant to offer a plausible account of free will, continues to this day. Scholars presuming Epicurean free will to have been synonymous with "conscious chance" (Bailey in Lucretius 1947, 3: 1287) are opposed by others who think that Epicurean freedom "fits random actions, rather than deliberate and purposive ones" (Furley 1967, 232-233). According to Furley's interpretation, the point of the swerve is merely to allow for a discontinuity in an 
otherwise deterministic succession of causes, and thereby to assure that the source of a human action can be traced in the agent himself and not in external factors. It does not, however, account for anything like a conscious free action. ${ }^{7}$

If we return our glance to Cicero's analysis of Epicurus, we will find that he opposes Epicurus' worldview not only to that of the older atomist Democritus, but also to that of the Stoic philosopher Chrysippus, according to whom "all things happen by fate and spring from eternal causes governing future events" (Cicero 1941, On Fate, 21). Indeed, it would seem that the Greek Stoics held that there exists a rational organizing principle that is found in all things in the world and which determines the course of all events. It is obvious that such a view "leaves no room for alternative developments of the world. There is exactly one course of events (and states) that is in accordance with the rational universal nature" (Bobzien 1998, 31).

While this type of strict determinism might have been compatible with Democritean atomism, it clearly wasn't with Epicurus'. From Plutarch's On Stoic Self-Contradictions, we know that Chrysippus derided the argument according to which the soul "takes a swerve of itself and resolves the perplexity." He replied "that the uncaused is altogether non-existent," and warned that "obscure causes insinuate themselves" whenever events appear to happen by chance. In the context of the etymological link between the words "chance" and "hazard" and the throwing of dice, to which we have drawn attention in our previous section, it is interesting to find Chrysippus insisting that dice and scales "cannot fall or incline now one way and now another without the occurrence of some cause" (Plutarch 1976, On Stoic Self-Contradictions 1045). The fact that we do not know how the dice will fall does not mean that there is no cause behind their specific fall.

\subsection{On Divination and Providence}

Let us conclude our section on Antiquity by listening once more to Cicero, and more specifically to his attack on divination, the power to foretell the future. His critique contains important reflections on chance, necessity and the knowledge of the course of nature. As the Latin word divinatio clearly indicates, the seer's knowledge of the future is "divinely inspired." This meaning implies that you can only know the future, first, if a god has predetermined it, and secondly, if this god

\footnotetext{
${ }^{7}$ Furley's interpretation was challenged by Fowler (1983) and Purinton (1999), who attribute to Epicurus and Lucretius the view that random swerves are indeed the cause of all voluntary actions. Bobzien (2000) agrees with Furley that the swerve is not responsible for every voluntary action, while O'Keefe (2005) 17, goes as far as to deny that the swerve plays any role in the production of action. While the above-mentioned interpretations are concerned with upward causation (from the atomic to the macroscopic level), David Sedley believes that Epicurus' denial of Democritus' determinism "involves an express assertion of downward causation": volitions are not influenced by, but instead influence atoms' motion (Sedley 1988, 318).
} 
has also revealed his or her plans to the seer. At some point in his De divinatione, Cicero criticizes specifically the view that "divination is the foreknowledge and foretelling of events considered as happening by chance [res fortuitae]," that is to say, of things which, "for though they happen frequently they do not happen always" (Cicero 1923, On Divination 2.5.13-14). Cicero retorts that physicians, pilots or military men continuously make predictions concerning future events, which are however based on science, experience, skill and wisdom. But in the absence of such professional knowledge, can there be

any foreknowledge of things for whose happening no reason exists? For we do not apply the words "chance," "luck," "accident," or "casualty" except to an event which has so occurred or happened that it either might not have occurred at all, or might have occurred in any other way. How, then, is it possible to foresee and to predict an event that happens at random, as the result of blind accident, or of unstable chance? (Ibid., 2.5.15).

Indeed - Cicero concludes - the very idea of foretelling what is random is self-contradictory! For this reason,

it is not in the power even of God himself to know what event is going to happen accidentally and by chance [casu et fortuito]. For if He knows, then the event is certain to happen; but if it is certain to happen, chance [fortuna] does not exist. And yet chance does exist, therefore there is no foreknowledge of things that happen by chance (ibid., II.7.18).

Cicero's reflections on divine foreknowledge provide us with a perfect bridge to the Christian Middle Ages, in which the divine predicates of omniscience and omnipotence forced the discussion about the status of chance, coincidence, fortune and luck in new directions, although the logical possibilities had already been defined by Greek and Latin philosophers. Irrespective of whether ancient philosophy was the cradle of Christianity or rather an obstacle to be overcome, we cannot understand medieval discussions without Greek philosophy.

It is evident that in a cosmos created and ruled over by an eternal, omniscient, and omnipotent God, mere chance can have no place. Whatever happens must have been known to God even before it happened; whether that implies that God also willed it, is a different and theologically difficult question. Is all "pro-vidence," in the sense of "fore-seeing," also "providence" in the sense of "benevolent guidance?" God must have foreseen the Fall of Adam and Eve; but it presumably was not an intended part of his plan.

However one may wish to settle this tricky issue, for Saint Augustine, the most influential of the Latin Church Fathers, it was obvious that there existed a personal type of divine providence, which implied that whatever happened, was - at least for God, the source of all providence - a rational event. This meant that no event was ultimately fortuitous and without reason: "those things that seem fortuitous come about by hidden forces" (Augustine 1841, Quaestiones in Heptateuchum, I. 91), just as generally, "the world is not governed by blind fate, but by the providence of a highest God, just as the Platonists also maintain" (Augustine 1998, 9.13.2). For most Christian authors, these two ideas were indeed linked, and necessarily so because of the divine predicates. On the one hand, there was God's omniscience, 
which left no room for mere chance in the sense of unpredictability - we have seen that Cicero had already pointed to this logical incompatibility even before the advent of Christianity. On the other hand, there was God's omnipotence, which implied that whatever happened, had to happen, and since God was benevolent, whatever happened, also had a positively providential aspect to it - an idea that Saint Augustine attributes to the Platonists.

\subsection{Boethius}

But if God is omnipotent and benevolent, and if everything is providential, how should we then explain the presence of evil in this world? This so-called problem of theodicy was addressed by another early Christian author, Boethius, whom we have encountered earlier in our essay, and who tried to correlate the three causal terms of "necessity," "free will" and "chance." Against the Stoics, Boethius insisted on the existence of a free will and argued against determinism; and against the Epicureans, he defended a plurality of causes, and rejected atomic monocausalism (Boethius 1891). While developing his solution to this problem, he drew a distinction between "divine providence" and "fate." These two terms, he explained, referred to the same thing, but did so from a different perspective:

The mind of God has set up a plan for the multitude of events. When this plan is thought of as in the purity of God's understanding, it is called Providence, and when it is thought of with reference to all things, whose motions and order it controls, it is called by the name the ancients gave it, Fate. [...] Providence includes all things at the same time, however diverse or infinite, while Fate controls the motion of different individual things in different places and in different times. So this unfolding of the plan in time when brought together as a unified whole in the foresight of God's mind is Providence; and the same unified whole when dissolved and unfolded in the course of time is Fate.... (Boethius 2000, IV.6p).

Boethius applies a similar perspectival approach to the existence of chance. In a world governed by providence, there was of course no space for chance; still, there was a sense in which something could be said to "happen by chance":

\footnotetext{
Whenever anything is done for one reason, but something other than what was intended happens on account of other reasons, it is called chance [casus]. [...] Therefore, we can define chance as an unexpected event brought about by a concurrence of causes which had other purposes in view. These causes come together because of that order which proceeds from inevitable connection of things, the order which flows from the source which is Providence and which disposes all things, each in its proper time and place (Boethius 2000, V.1p).
}

It is no coincidence that in the same chapter from which these quotes are drawn, Boethius refers to Aristotle's Physics. Indeed, Aristotle's tuchê and Boethius' casus have in common that they are the non-intended by-products of intended actions. We have earlier encountered Aristotle's example of the man who went to the market and there happened to encounter his debtor. Boethius' main example is also taken 
from Aristotle (Metaphysics V, 30), and is that of a man who goes to his field to plant a tree and happens to find a treasure. But what to us seems mere chance, is in reality only a concurrence (concursus) of causally accountable circumstances. After all, someone must have buried the gold in the field in the first place. For Boethius, the concept of casus is thus not only incompatible with providence, but also with the causal structure of the world. A real casus would not only be inexplicable, but would be uncaused, or, in Boethius' terms, ex nihilo. This identification of casus with ex nihilo events is not taken from Aristotle, but might be indicative of Boethius' debt to Stoic determinism.

\subsection{Late Medieval Views on Chance}

In fact, even when they read and used Aristotle on the issue of chance, Christian authors were generally driven by different concerns than their admired Greek preceptor. Several centuries after Boethius, for example, Peter Abelard defined "chance as an unexpected event" (inopinatus eventus). He insisted that what is to blame is not the event itself, but only our own lack of understanding: "the word 'chance' ... denotes always ignorance" (Peter Abelard 1919, 426). The common medieval view that "chance" is always "in us, not in the things," agrees with Aristotle's view that chance does indeed denote ignorance, in the sense that it defies our scientific grasp of the underlying causal pattern, but it deviates from Aristotle in correlating this ignorance with the rare, irregular and indeed "casual" nature of a given event.

Apart from the obvious impact of a monotheistic conception of an all-powerful God running the universe on discussions regarding chance, fortune and accident, when one examines the later Middle Ages, one cannot but be impressed by the acuity with which these and related words were examined. Ever since the seventeenth century, the so-called scholastics have been derided because of the bookish nature of their knowledge claims and their delight in hair-splitting controversies. But precisely their trust in the authority of the authors of the books they commented on and their attention to even the most abstruse interpretative possibilities implied that they were good readers and careful observers of language. Having to examine and reconcile ideas from various traditions - Greek and Latin philosophy, Jewish and Christian theology - they were aware of the abundance of different terms that were used to express similar ideas. They noticed, for example, that casus, contingentia and fortuna described similar and often even identical events, although the meaning of some of the words was more general than that of others (e.g., John Buridan 1509, 36rb). They also noticed that casus, "chance," was applied to both causes and effects - an observation to which we have already drawn attention in our own introduction (e.g., Roger Bacon 1935, 116). Many of their considerations regarding contingency (notably in their analysis of the status of future contingents), non-essential predicates (accidentia), the concomitance of various "coinciding" 
causes, or the nature of "fortuitous events" (eventus fortuiti) were indeed ground-breaking.

Let us end our medieval section with Thomas Aquinas, who in his famous Summa theologiae examined the relation between chance, fate and divine providence. Invoking positions that we have encountered earlier in our chapter, Thomas refers to Aristotle's conception of chance, quotes Augustine's view that there is neither chance nor luck in the world as all events are foreseen, and cites Boethius, for whom the word "fate" referred to an inherent disposition of things by which divine Providence brings about the desired effects. Christianizing the Aristotelian distinction between the regularity encountered in the supralunary world and the disorder found in the sublunary world, Thomas explains that "what happens on earth accidentally, either in nature or in human affairs, is derived from a pre-ordaining cause, namely Divine Providence" (Thomas Aquinas 1964-1976, vol. 15, Summa Theologiae, Part 1, art. 116, qu. 1). Only when explained in terms of their proximate causes do things happen by luck or chance, but not when explained in terms of divine providence, whereby "nothing happens randomly in the world" (ibid.).

In the second book of the Summa contra gentiles, which deals with the creation of the world, Thomas devotes a chapter to the question of whether "the distinction of things," that is to say their separation into genera and species, is the result of chance. His answer, which relies on Aristotle's so-called hylemorphist doctrine, according to which all substances are constituted by matter and form, is that all individuals belonging to a species share the same form, and that it is matter that is responsible for individual differences. Given that "chance is found only in things that are possibly otherwise," Thomas argues that "the distinction of things in terms of species cannot be the result of chance," as the forms (which define the species) are by definition unchangeable. By contrast, differences between individuals belonging to the same species "can perhaps be the result of chance," because matter is "a reservoir of multiple possibilities" (Thomas Aquinas 1975a, II. 39). As Norman Kretzmann has explained, for Aquinas, the existence of, say, a particular pigeon is a chance state of affairs, not because it is uncaused, but because it is "the result of an unplanned convergence of two or more previously independent series of causes" (Kretzmann 1999, 208). Thomas seems to suggest that "the generating of individual members of species of plants or of non-human animals" may take place "apart from" (praeter), although "of course not contrary to, the intention of the creator/distinguisher" (ibid., 209). Humans, "metaphysical hybrids" composed of a body and a soul, are the only individual beings whose coming-into-existence and life-course cannot take place without an divine intentional act (ibid., 209).

In the third book of the Summa contra gentiles, Thomas invokes Aristotle's example of the casual encounter between a man and his debtor to show that providence does not exclude chance: "It would be contrary to the essential character of divine providence if all things occurred by necessity (...). Therefore, it would also be contrary to the character of divine providence if nothing were to be fortuitous and a matter of chance in things" (Thomas Aquinas 1975b, III. 74). 


\subsection{Chance, Necessity and Design in a Mechanistic Universe}

From what little has been said, it must be clear that Thomas Aquinas involves God where he must, but for the rest tries to leave space for contingency. According to Anneliese Maier, this wiggling space was to disappear within a century after Thomas' death. Maier is convinced that a noteworthy development took place in the fourteenth century, which was going to shape the entire period up to the twentieth. Most scholastics had previously insisted, just like Thomas, that each and every natural event required a cause, but that not everything took place ex necessitate. In the fourteenth century, however, a more restrictive view came to prevail according to which contingency - understood as the contrary of necessity, as something that could be thus but also otherwise - could only be encountered in the realm of voluntary acts (Maier 1949, 241). Maier boldly suggests that from the fourteenth century to the advent of quantum mechanics in the twentieth, there existed an underlying consensus that excluded contingency from the natural world:

[...] for the [divine] first cause, there exists no Zufall [chance/coincidence/randomness]. But this means: taken by itself, there exists no Zufall at all in the world, but only in a relative sense, in respectu, that is, only with respect to specific and particular causes and only for those who are not capable of surveying the concursus causarum [concourse of causes] (Maier 1949, 231, our translation).

As we will see below, Maier's bold thesis is probably mistaken for the nineteenth century, but it is quite convincing for the period that we tend to describe as the Scientific Revolution, and notably for the seventeenth century. That century witnessed the emergence of the idea of a physical world governed by laws of nature, which were universally valid and admitted no exception. In the mechanistic universe that became so fashionable in the second half of the century, nothing could happen at random, so that the word "chance" could at best designate events that provoked a subjective feeling of surprise while being inherently necessary.

It might at first sight appear paradoxical that the probability calculus originated precisely in that deterministically minded seventeenth century, in the hands of mathematicians like Blaise Pascal, Pierre de Fermat and Christiaan Huygens. Until the Renaissance, the adjective "probable" had been used to designate an opinion which was based not on a demonstration, but on a reliable authority (Byrne 1968). Only in the second half of the seventeenth century did a mathematical notion of probability emerge (Hacking 1975, 11). According to Ian Hacking, who in an unsurpassed historical analysis has reconstructed the history of probabilistic thinking, early-modern determinism, far from precluding any thought about randomness, in fact paved the way for the mathematical study of chance and probability (ibid., 3). A similar point has been made by Lorain Daston, according to whom "determinism, far from stifling mathematical probability theory, actually promoted it" (Daston 1988, 37). To be sure, in his little Liber de ludo aleae ("Book on the game of dice") of 1520, Gerolamo Cardano had already tried to calculate the probability of various dice throws, but had still attributed the discrepancy between calculated and actual 
outcome to the intervention of fortuna (ibid., 36). But once chance and fortuna had both been banned from the deterministic world of seventeenth-century natural philosophy, a new way of calculating probabilities had to emerge. As Hacking has pointed out, the early modern notion of probability is, however, "Janus-faced: on the one side it is statistical, concerning itself with stochastic laws of chance processes; on the other side it is epistemological, dedicated to assessing reasonable degrees of belief in propositions quite devoid of statistical background" (Hacking 1975, 12).

No one captures the substitution of the Lady of Chance, Fortuna, by a conception of chance as mathematical and epistemic probability better than the Scottish philosopher David Hume. In the chapter "Of Probability" of his An Enquiry Concerning Human Understanding, he introduced a crucial distinction between "Chance," written with a capital letter, and mere "chances":

Though there be no such thing as Chance in the world (....) there is certainly a probability, which arises from a superiority of chances on any side; and according as this superiority increases, and surpasses the opposite chances, the probability receives a proportionable increase, and begets still a higher degree of belief or assent to that side, in which we discover the superiority. If a dye were marked with one figure or number of spots on four sides, and with another figure or number of spots on the two remaining sides, it would be more probable, that the former would turn up than the latter; though, if it had a thousand sides marked in the same manner, and only one side different, the probability would be much higher, and our belief or expectation of the event more steady and secure. This process of the thought or reasoning may seem trivial and obvious; but to those who consider it more narrowly, it may, perhaps, afford matter for curious speculation. (Hume 1748, Ch. 6).

Similarly, Hume's French contemporary, Voltaire, was convinced that "chance is nothing, and that we have invented this word to describe the known effect of un unknown cause." Voltaire expressed this view in Le philosophe ignorant (Voltaire 1766, Ch. 13) as well as in the entry "On atoms" of the Philosophical Dictionary, in which he explained that seventeenth-century mechanical philosophers

distinguished what is good in Epicurus and Lucretius, from their chimeras, founded on imagination and ignorance (...). All have acknowledged that chance is a word without meaning. What we call chance can be no other than the unknown cause of a known effect. Whence comes it then, that philosophers are still accused of thinking that the stupendous and indescribable arrangement of the universe is a production of the fortuitous concurrence of atoms - an effect of chance? Neither Spinoza nor any one else has advanced this absurdity (Voltaire 1901, s.v.).

Although very critical of the Church and of revealed religion, Voltaire was convinced, as a Deist, that the existence of God could be inferred from the order of the natural world. In the entry on "God/Gods" of the Philosophical Dictionary he in fact claimed:

Every work which shows us means and an end, announces a workman; then this universe, composed of springs, of means, each of which has its end, discovers a most mighty, a most intelligent workman. Here is a probability approaching the greatest certainty. (...) I am aware that various philosophers, and especially Lucretius, have denied final causes (...). To affirm that the eye is not made to see, nor the ear to hear, nor the stomach to digest - is not this the most enormous absurdity, the most revolting folly, that ever entered the human mind? (Voltaire 1901, s.v.). 
Voltaire could not ignore the fact that Spinoza had launched a powerful attack against the doctrine of final causes. In the famous Appendix to the first book of his Ethics, Spinoza had argued that the idea that "God directs all things to a definite goal" was a widespread misconception, which hindered "the understanding of the concatenation of things." According to Spinoza, God is the only substance that exists and "acts solely by the necessity of his own nature." All things "are in God" and are "predetermined by God, not through his free will or absolute fiat, but from the very nature of God or infinite power." Being "ignorant both of things and their own nature," people wrongly "believe that there is an order in things" and that "God has created all things in order." This misconception, Spinoza maintained, is the product of a double fallacy. People mistakenly "think themselves free, inasmuch as they are conscious of their own volitions and desires" and from this they wrongly conclude that "all things in nature act as men themselves act, namely, with an end in view" (Spinoza 1883, 75-81; Ethics, Appendix to Part I).

In his Philosophical Dictionary, Voltaire tried to convince his readers that, contrary to Lucretius and other ancient philosophers, Spinoza could not "help admitting an intelligence acting in matter, and forming a whole with it." In Voltaire's eyes, Spinoza "did not understand himself":

If this infinite, universal being thinks, must he not have design? If he has design, must he not have a will? Spinoza says, we are modes of that absolute, necessary, infinite being. I say to Spinoza, we will, and have design, we who are but modes; therefore, this infinite, necessary, absolute being cannot be deprived of them; therefore, he has will, design, power (Voltaire 1901, s.v. God/Gods).

That Spinoza would have rejected Voltaire's interpretation without further ado is clear from some letters he wrote to Hugo Boxel, a Dutch contemporary who tried to persuade him of the existence of ghosts. In a letter dated 21 September 1674, Boxel had claimed that "it appertains to the beauty and perfection of the universe" that "there are spirits of all sorts, but, perhaps, none of the female sex," adding that his reasoning would not convince those "who rashly believe that the world has been created by chance." In his answer, Spinoza could not avoid addressing the question, "whether the world was made by chance." He insisted that "chance and necessity are two contraries," so that

\footnotetext{
he, who asserts the world to be a necessary effect of the divine nature, must utterly deny that the world has been made by chance; whereas, he who affirms, that God need not have made the world, confirms, though in different language, the doctrine that it has been made by chance; [...]. I, myself, lest I should confound the divine nature with the human, do not assign to God human attributes, such as will, understanding, attention, hearing, \&c. I therefore say, as I have said already, that the world is a necessary effect of the divine nature, and that it has not been made by chance" (Spinoza 1883, 381).
}

In his reply, which is unfortunately lost to us, Boxel must have objected that the opposite of "necessity" is not "chance," but "freedom." Spinoza reacted with astonishment: 
I am [...] at a loss for the reasons, with which you want to make me believe, that chance and necessity are not contraries. [...] As soon as I affirm that heat is a necessary effect of fire, I deny that it is a chance effect. To say, that necessary and free are two contrary terms, seems to me no less absurd and repugnant to reason. For no one can deny, that God freely knows Himself and all else, yet all with one voice grant that God knows Himself necessarily (Spinoza 1883, 385).

Returning to Voltaire, we may now declare that although he did not do justice to Spinoza's philosophical views, he was yet quite right in stating that no early modern mechanical philosopher had regarded chance as an explanatory cause of physical phenomena. Other eminent examples confirm this opinion clearly. Pierre Gassendi, one of the founding fathers of early-modern atomism, explicitly claimed that "chance is nothing in itself (..), but the lack of foreknowledge and of the intention of an event" (Gassendi 1658, 2: 829a). He borrowed from ancient atomism the idea that all physical phenomena could be explained in terms of the motion of minute particles of matters, but criticized Epicurus for turning chance (fortuna) into a cause. In Gassendi's eyes, Epicurus' recourse to the swerve to explain the formation of the world and to account for human freedom was no convincing alternative to the determinism of Democritus and of the Stoics, because whatever happens "by a variety of motions, collisions, rebounds, swerves" still happens by necessity (ibid., 2: 838). Margaret Osler has rightly pointed out that

\footnotetext{
in order to embrace the evident facts of both causal order and contingency within the bounds of his mechanical philosophy, Gassendi undertook a Christian reinterpretation of the concepts of fate, fortune, and chance [...]. Fate is nothing more than God's decree, and fortune and chance are expressions of contingency in the world coupled with human ignorance of the causes of fortuitous events (Osler 1994, 92, with references to Sarasohn 1985).
}

Gassendi, who is usually dismissive of Aristotelian philosophy, here invoked, just as Boethius had done centuries earlier, Aristotle's example of the man who digs the ground to plant a tree and accidentally finds a treasure in order to explain that chance is the "concourse" of two independent causal chains (Gassendi 1658, 2: 828 b). And, like Boethius, Gassendi also claimed that chance events are "part of divine providence," which "includes things which are foreseen as well as things which are unforeseen to humans" (ibid., 2: 840b).

A position analogous to Gassendi's - accepting atomism, but rejecting Epicurus' random swerves as explanatory tool in physical and psychological matters - was endorsed by the chemist Robert Boyle, one of the central figures of the early Royal Society and the person to render "the mechanical philosophy" programmatic. In his About the Excellency and Grounds of the Mechanical Hypothesis (1674), Boyle wrote:

When I speak of the Corpuscular or Mechanical Philosophy, I am far from meaning with the Epicureans that Atoms, meeting together by chance in an infinite Vacuum, are able of themselves to produce the World, and all its Phaenomena (Boyle 2000a, 103; cf. Fig. 2).

In his treatise, Boyle took issue not only with Epicurus, but also with "some modern philosophers" who suggested that all God had to do in order "to make the 


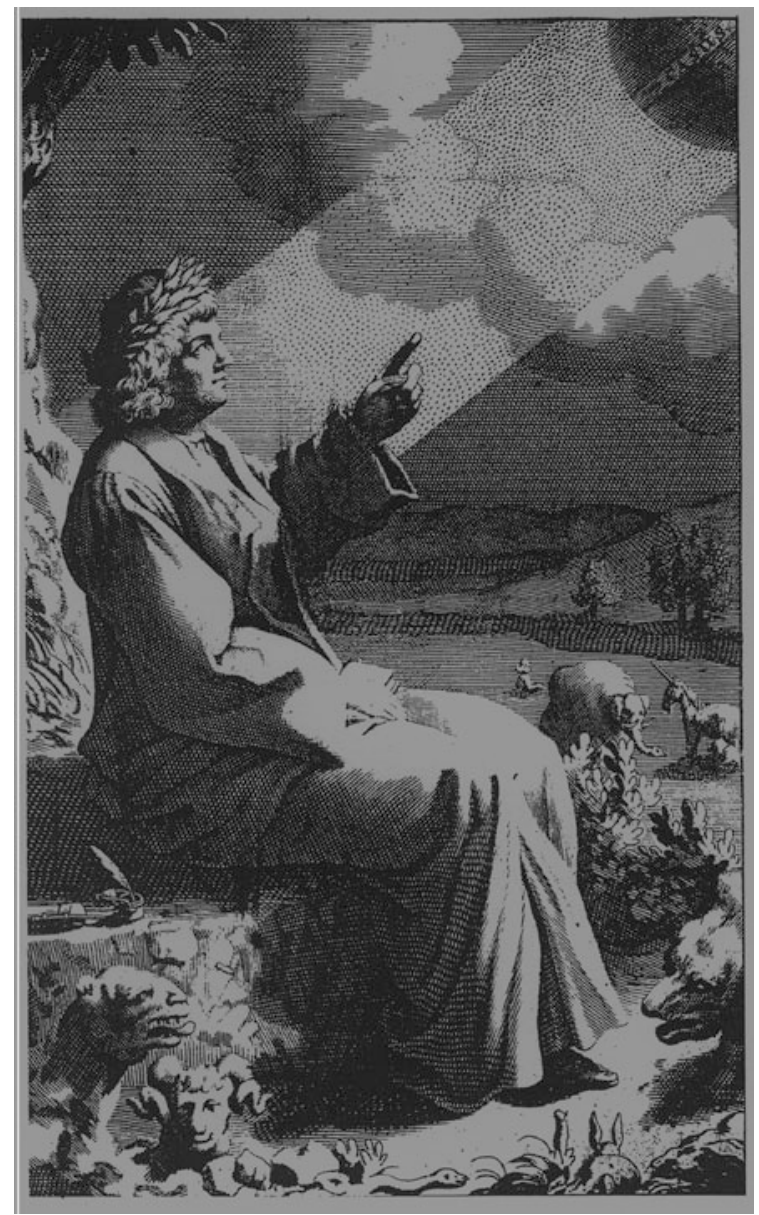

Fig. 2 The seventeenth century's difficulty of depicting "chance" and "randomness." It is literally no coincidence that of the 79 editions of Lucretius' De rerum natura printed between 1473 and 1725, only one contains a depiction of atoms, namely the third edition of Thomas Creech's English translation of 1683. But what an ambivalent image it is! We see Lucretius gesturing at dots descending — without any swerve! - from a celestial globe carrying the name "chance" (CASUS). How "chance" can generate these dot-atoms is left unexplained, and it also remains entirely unclear how a single type of dot-atoms can bring about the variety of life forms seen emerging out of mud at the bottom of this frontispiece. In case the dots descending in a diagonal shaft of light are intended as a reference to dust motes dancing in sunbeams, then the image is even more misleading, because Lucretius denies explicitly that the motes are atoms; they are merely similar to them (rei simulacrum et imago). (See Lüthy 2003, 122) 
world" was to impart motion to "the whole mass of matter (...), the material parts being able by their own unguided motions to cast themselves into such a system." The type of mechanical philosophy that Boyle was defending was quite different, for it

reaches but to things purely corporeal [and hence not to the soul], and distinguishing between the first original of things; and the subsequent course of Nature, teaches concerning the former, not only that God gave Motion to Matter, but that in the beginning $\mathrm{He}$ so guided the various motions of the parts of it, as to contrive them into the World (...) and establish'd those Rules of Motion, and that order amongst things corporeal, which we are wont to call the Laws of Nature. And having told this as to the former, it may be allowed as to the latter to teach, that the Universe being once fram'd by God, and the laws of motion being settled and all upheld by this incessant concourse and general Providence; the Phaenomena of the world this constituted, are Physically produced by the mechanical affections of the parts of matter, and what they operate upon one another according to Mechanical laws (Boyle 2000a, 103-104).

In this passage, Boyle addresses two of the most debated issues of early-modern philosophy, namely the nature of corporeal things and the relation between God and his creation. Boyle's first remark must be read as an answer to materialist philosophers like Thomas Hobbes, who believed that the soul, being corporeal, was subjected to the same immutable laws that governed the behaviour of physical bodies. The second remark is an expression of what John Henry called "an unmistakably voluntarist position" (Henry 2009, 94). Whereas intellectualists insisted that God had created the best of all possible worlds, of which there could only be one, so that God was limited in his choice, voluntarists regarded creation as an act of God's will and therefore as freely chosen. In the Free Enquiry into the Vulgarly Received Notion of Nature (1686), Boyle wrote:

God is a most Free Agent, and Created the World, not out of necessity, but voluntarily, having fram'd It, as he pleas'd and thought fit, at the beginning of Things, when there was no Substance but Himself, and consequently no Creature, to which He could be oblig'd, or by which he could be limited (Boyle 2000b, 566).

In a similar vein, in a manuscript note redacted around 1672, Isaac Newton wrote: "The world might have been otherwise than it is (because there may be worlds otherwise framed than this). It was therefore no necessary but a voluntary \& free determination that it should be thus" (Newton, MS Yahuda 21, fol. 2r, spelling adjusted, quoted from Henry 2009, 96).

The most famous clash between voluntarism and intellectualism is the controversy between Gottfried Wilhelm Leibniz and the Newtonian theologian Samuel Clarke. In his letters, Leibniz repeatedly stressed that nothing in nature "happens without a reason why it should be so, rather than otherwise" (Leibniz, Second Letter, $\S 1$; in Alexander 1956, 16). If there really did exist an absolute space, as Newton believed, which was ontologically independent from the bodies contained in it, then the act of creation would have included an element of arbitrariness, for God would have had no reason to order objects "after one certain particular manner rather than otherwise" (Leibniz, Third Letter, $\S 5$; ibid., 26). Clarke agreed with Leibniz that "nothing is, without a sufficient reason, why it is, and why it is thus rather than otherwise," but in his eyes, "this sufficient reason is oft-times no other, than the will 
of God." For Clarke, to deny to God the power of determining "why this particular system of matter, should be created in one particular place, and that in another particular place," meant nothing less than "to take away all power of choosing, and to introduce fatality" (Clarke, Second Letter, § 1; ibid., 20). On his account, then, intellectualism implied fatalism. Leibniz, on the other hand, accused Newton and Clarke of reintroducing chance into the world: "A will without reason, would be the chance of the Epicureans. A God, who should act by such a will, would be a God only in name" (Leibniz, Fourth Letter, § 18; ibid., 39). Clarke rejected this objection. In his eyes, "the Epicurean chance is not a choice of will, but a blind necessity of fate" (Clarke, Fourth Letter, § 18; ibid., 50). But Leibniz, conceiving of the relation between chance, choice, necessity and fate differently, retorted: "Epicurus' chance is not a necessity, but something indifferent. Epicurus brought it in on purpose to avoid necessity. ' $\mathrm{T}$ is true, chance is blind; but a will without motive would be no less blind, and no less owing to real chance" (Leibniz, Fifth Letter, § 39; ibid., 79).

This opposition sheds much light on our issue. For Leibniz, the word "chance" designates the absence of a determining cause, and it can hence be applied to whatever happens without a reason. For Clarke, by contrast, "chance" implies "involuntariness," so that no free agent can be said to operate by chance:

comparing the will of God, when it chooses one out of many equally good ways of acting, to Epicurus' chance, who allowed no will, no intelligence, no active principle at all in the formation of the universe; is comparing together two things, than which no two things can possibly be more different (Clarke, Fifth Letter, § 70; ibid., 107-108).

Leibniz considered his own metaphysics, which was based on the idea that an omnipotent God cannot fail to choose the best, to be the only viable alternative to the determinism of Spinoza, according to whom everything that exists flows necessarily from the essence of God. In Clarke's eyes, however, Leibniz' worldview was as necessitarian as Spinoza's: to claim that "whatever God can do, he cannot but do (...) is making him a mere necessary agent, that is, indeed no agent at all, but mere fate and nature and necessity" (Clarke, Fourth Letter, § 22-23; ibid., 50).

\subsection{Hume's Critique of the Argument from Design}

Precisely because the relation between chance, will, reason, and necessity can be thought of in such radically different ways, David Hume was to insist on the importance of agreeing over the definition of these terms. In his Treatise of Human Nature, Hume explains that no "freedom of indifference" can exist, if it is defined as "that which means a negation of necessity and causes":

According to my definitions, necessity makes an essential part of causation; and consequently liberty, by removing necessity, removes also causes, and is the very same thing with chance. As chance is commonly thought to imply a contradiction, and is at least directly contrary to experience, there are always the same arguments against liberty or free-will. If any one alters the definitions, I cannot pretend to argue with him, until I know the meaning he assigns to these terms (Hume 2007, pt. 3, s. 1). 
In other words, that voluntary actions are caused by the agent's will does not make them any less necessary than the behaviour of material objects: "the chance or indifference lies only in our judgment on account of our imperfect knowledge, not in the things themselves, which are in every case equally necessary, though to appearance not equally constant or certain" (ibid.).

The concept of "chance" plays an important role also in Hume's famous Dialogues Concerning Natural Religion. Cleanthes, one of the literary interlocutors, argues that the world exhibits too much order and harmony to be a mere product of chance:

Throw several pieces of steel together, without shape or form; they will never arrange themselves so as to compose a watch. Stone, and mortar, and wood, without an architect, never erect a house. (...) The adjustment of means to ends is alike in the universe, as in a machine of human contrivance. The causes, therefore, must be resembling (Hume 1779, 56).

Hume's spokesman, Philo, suggests that Cleanthes' reasoning rests on a weak analogy. The dissimilitude between a house and the universe "is so striking, that the utmost you can here pretend to is a guess, a conjecture, a presumption concerning a similar cause." Moreover, one should not suppose that the attributes of God "have any analogy or likeness to the perfections of a human creature." We ascribe to God "Wisdom, Thought, Design, Knowledge (...) because these words are honourable among men," forgetting that "He is infinitely superior to our limited view and comprehension" (Hume 1779, 46).

Now, whereas Cleanthes argues that what cannot be the outcome of chance must be the result of design, Philo adds a third term to the disjunction, namely necessity. He illustrates his point by means of an interesting piece of mathematical reasoning:

It is observed by arithmeticians, that the products of 9 , compose always either 9 , or some lesser product of 9 , if you add together all the characters of which any of the former products is composed. Thus, of $18,27,36$, which are products of 9 , you make 9 by adding 1 to 8,2 to 7, 3 to 6 . Thus, 369 is a product also of 9; and if you add 3, 6, and 9, you make 18 , a lesser product of 9 . To a superficial observer, so wonderful a regularity may be admired as the effect either of chance or design: but a skilful algebraist immediately concludes it to be the work of necessity, and demonstrates, that it must for ever result from the nature of these numbers. Is it not probable, I ask, that the whole economy of the universe is conducted by a like necessity, though no human algebra can furnish a key which solves the difficulty? And instead of admiring the order of natural beings, may it not happen, that, could we penetrate into the intimate nature of bodies, we should clearly see why it was absolutely impossible they could ever admit of any other disposition? So dangerous is it to introduce this idea of necessity into the present question! and so naturally does it afford an inference directly opposite to the religious hypothesis! (Hume 1779, 168).

However ingenious Hume's triptych of possibilities, which is composed of design, chance and necessity may have been, and however modern Hume was in many other respects, with respect to biology, things turned out differently. What emerged in the late eighteenth century and culminated in the mid-nineteenth was an evolutionary account of life forms in which neither design, nor necessity, but chance would in fact provide the required explanans. 


\subsection{From Natural History to Darwinism}

In the domain of natural history — what would later become biology and geologythe eighteenth century ushered in a more chaotic world-view. God receded from his previous role as the designing creator as well as the guarantor of an all-pervasive necessity, as our world gradually turned out to have a tempestuous past made of ice ages, inundations, volcanic eruptions, extinct species and ultimately of forms of life that diversified in unpredictable ways in reaction to these circumstances.

Indeed, an impressive and ever increasing battery of eminent authors emerged who would deny the distinction, which Anneliese Maier ascribes to this time period, between a contingent realm of human action and a deterministic realm of nature. One may observe, beginning in the eighteenth century, an increasing insistence on the accidental nature of all forms of life, including man. Julien Offray de La Mettrie, in his famous L'Homme machine, provocatively stated that human existence had been thrown upon the Earth au hazard, "just like mushrooms," mushrooms being at the time in many quarters still seen as imperfect beings that were generated spontaneously (La Mettrie 1764, 46). And as biologists began to get an inkling of the changing morphology of species, they arrived at the concomitant idea of "innumerable multitude of individuals" produced by "chance" (hazard) and of "fortuitous combinations of the productions of nature," of which the species living today are only "a small part of what blind fate [un destin aveugle] has produced" (Maupertuis 1752).

The epitome of that trend is of course Charles Darwin's On the Origin of Species of 1859 , which introduces the notion of a blind natural selection, which relies on a very simple combination of factors: there is a random type of variation of traits found among siblings (a longer or shorter neck, thicker or thinner fur, greater or lesser need of water, etc.); a deadly struggle for survival due to the presence of predators, a perennial excess of offspring and the resulting scarcity of food and resources; and the resulting selection of those randomly generated traits that happen to give their owners an advantage in the struggle for survival. These traits, selected again and again across numerous generations, would eventually lead to such modifications in a population that a new species or even genus could come about (Darwin 1859). Importantly, there existed, for Darwin, no underlying evolutionary direction or logic. The environmental factors were as accidental as the traits they selected among the randomly generated variants. Whether a thicker fur happened to be an advantage or a disadvantage for survival depended on changing weather patterns, diseases, the presence of predators and many other unpredictable conditions. C. S. Lewis mocked this vision of nature in the first lines of his satirical Evolutionary Hymn:

Lead us, Evolution, lead us

Up the future's endless stair;

Chop us, change us, prod us, weed us. 
For stagnation is despair:

Groping, guessing, yet progressing,

Lead us nobody knows where (Lewis 1964, 55).

Lewis parodies here a famous hymn by James Edmeston (1821), which to this day is found in all Anglican and Episcopalian hymnals and whose first verses sound as follows:

Lead us, heavenly Father, lead us

o'er the world's tempestuous sea;

guard us, guide us, keep us, feed us,

for we have no help but thee;

yet possessing every blessing,

if our God our Father be.

The opposition between the invocation of divine providence, in the original hymn, and Lewis' ironical description of the total absence thereof in an evolutionary process that chops and weeds aimlessly and without purpose and direction is stark. But the lack of providentialism is clearly expressed in Darwin's model:

In such case, every slight modification, which in the course of ages chanced to arise, and which in any way favoured the individuals of any of the species, by better adapting them to their altered conditions, would tend to be preserved; and natural selection would thus have free scope for the work of improvement. (Darwin 1859, Ch. 4).

Darwin honestly admitted that he had no idea about the forces that were responsible for the variability of traits found in offspring. After all, Mendel, genetics, and the discovery of DNA were later episodes in the history of biology. Nevertheless, his basic model has remained fairly intact, as has the role of chance in it. For example, modern biology speaks of the role of mutations in the evolution of species in terms of spontaneous mutations (such as molecular decay) or mutations due to errors occurring in the replication of DNA. The default process is faithful copying, but errors take place a bit like the sudden swerve or klinamen of atoms, unexplained deviations from the usual direction. ${ }^{8}$

In the eyes of the American philosopher, logician, chemist and mathematician Charles Sanders Peirce, Darwin's evolutionary theory in fact constituted strong evidence against a deterministic world-view. Quite generally, Peirce combated the idea that the universe was governed by strict laws, preferring to see mathematical laws of nature as nothing more than statistical approximations to general patterns or "habits," as he called them, which natural bodies tended to exhibit. In fact, taking recourse to tuchê, the Greek word with which we begun our historical section, Peirce in 1892 coined the neologism "tychism" as the name of the view that the universe was characterized by "absolute chance," not by a deterministic type of "necessity." Peirce dismissed the idea "that every single fact in the universe is precisely determined by law" (Peirce 1892, 321). That mistaken idea had been around since the days of Democritus and the Stoics, but had in the meantime been

\footnotetext{
${ }^{8}$ See on this Han Brunner's chapter in this book.
} 
clad in new scientific clothes, looking thus: "Given the state of the universe in the original nebula, and given the laws of mechanics, a sufficiently powerful mind could deduce from these data the precise form of every curlicue of every letter I am now writing" (ibid., 323).

But-Peirce retorted - the so-called "laws of mechanics," like all laws of nature, were mere approximations. The more exact one's experimental measurements, the greater the deviations of the data from the mathematical ideal. In the essay's concluding dialogue between an imaginary determinist and Peirce, which starts with a discussion over whether the apparently random fall of a die is determined or not, the real force of tychism is finally introduced. In an evolving cosmos, which displayed ever-increasing complexity over time, all apparent mechanical regularity could at best be provisional. In other words, one had to admit "pure spontaneity or life as a character of the universe, acting always and everywhere though restrained within narrow bounds by law, producing infinitesimal departures from law continually, and great ones with infinite infrequency" (ibid., 333-334).

\subsection{Laplace's Determinism, Statistical Regularity and the New Physical Randomness}

A similar recovery of chance and randomness took place in the domain of physics. This occurred, paradoxically enough, after these concepts had been quite thoroughly expelled from the exact sciences. We have seen earlier that when medieval philosophers such as Abelard claimed that "the word 'chance' ... always denotes ignorance," they did so because they compared the low level of human comprehension with the omniscience of God, for whom nothing happened unexpectedly and for whom there existed no chance. But we also recall that in the seventeenth century, the idea emerged that if one managed to find all laws of nature, these would ultimately explain everything within a deterministic framework. In the latter paradigm, "chance" was no longer opposed to "divine providence," nor was it any longer the expression of the innate limits of human understanding. If humans attributed an event to "chance," this term had to do either with their personal ignorance of the physical laws causing the event in question, or else with the mathematical difficulty of deriving that particular event from the multiplicity of underlying causes and the respective laws governing them. This position was forcefully expressed by the French mathematician Pierre-Simon Laplace, whose name is associated with the development of statistical methods for calculating probabilities (Théorie analytique des probabilités 1812), with a scientific form of determinism, and with the concomitant elimination of divine causality from cosmology as well as physics quite generally. As the apocryphal story goes, he explained to Napoleon that he did not need God as a hypothesis ("je n'avais pas besoin de cette hypothèse-là"). His scientific determinism, in turn, expressed itself most famously in the notion of a "demon" - a kind of perfect intelligence - that 
could derive all current and future states of the world from a complete understanding of previous states:

We may regard the present state of the universe as the effect of its past and the cause of its future. An intellect which at a certain moment would know all forces that set nature in motion, and all positions of all items of which nature is composed, if this intellect were also vast enough to submit these data to analysis, it would embrace in a single formula the movements of the greatest bodies of the universe and those of the tiniest atom; for such an intellect nothing would be uncertain and the future just like the past would be present before its eyes (Laplace 1902, 4).

This is of course the very theory to which Peirce alluded when he said that the modern version of determinism pretended that "every curlicue of every letter I am now writing" had been predetermined by the state of the first stellar nebulae. Now, "Laplace's demon" is expressly not a god, and certainly not a creator, but rather a calculating device of the type that we would nowadays identify with a supercomputer. Nor is he, or it, omniscient and in fact need not even be conscious. All it does is to deduce, on the basis a complete set of natural laws and an equally complete data set on all bodies in the world, mechanically, and with absolute certainty, the present and future behaviour of the world and all that is in it.

But then, the century that started with Laplace ended with Peirce's rejection of the possibility the former's omniscient demon. Quite generally, it witnessed what Ian Hacking has described as a veritable "erosion of determinism" (Hacking 1983, 445). This erosion took place not only in philosophy and biology, but also in the domain of physics. 9

The probabilistic revolution in physics in fact clearly predated the advent of quantum theory. It all started in the mid-nineteenth century with what we now call "statistical mechanics" (Brush 1976, Ch. 4). This theory arose in the wake of thermodynamics and made the point that one fundamental assumption of classical physics, namely a complete specification of the state of a system as input for accurate and certain predictions (in keeping with the spirit of determinism), was hardly satisfied if the system in question consisted of $100,000,000,000,000,000,000,000$ particles, as is typically the case for a gas in a container.

While at first sight, this problem might still seem solvable by the hypothetical Laplacian demon, the everyday phenomenon of irreversibility in macroscopic systems turned out to be inexplicable on the assumption that probability was merely a matter of ignorance. Incidentally, this issue remains unresolved until the present day (Sklar 2009; Uffink 2007). In the late nineteenth century, at any rate, its recognition served as a first admonition with regard to a possibly fundamental (or "irreducible") role for probability in physics (Uffink 2014).

Another challenge to classical physics that fed probabilistic reasoning and attitudes consisted in the observation of discrete and discontinuous phenomena

\footnotetext{
${ }^{9}$ The following six paragraphs have been written by Klaas Landsman; we have imported only minor modifications.
} 
(especially at an atomic scale). Two of Einstein's four path-breaking articles in his annus mirabilis 1905 were concerned with such phenomena (Stachel 1998). The first article tackled the issue of Brownian motion - the motion of particles suspended in a fluid - and was based on the use of what is called "random walks," the latter term referring to a mathematical formalisation of a path such as that of a molecule in a liquid, which consists of a succession of random steps. Einstein's second article provided the first empirical confirmation of the quantum nature of light, that is to say, the fact that light manifests itself only in multiples of a basic unit. It was mainly the latter issue of discreteness and discontinuity, first discovered by Max Planck, Albert Einstein, and Niels Bohr, that eventually led to quantum mechanics (Jammer 1966).

After a period of confusion and crisis lasting from 1900 to 1925, which ended with the complementary work of Heisenberg on matrix mechanics in 1925 and of Schrödinger on wave mechanics in 1926, quantum mechanics was more or less finalized during the subsequent five years, apart from Werner Heisenberg and Erwin Schrödinger also through the remarkable contributions of Paul Dirac, Max Born, Pascual Jordan, Wolfgang Pauli, and John von Neumann. Quantum mechanics thereby replaced Newton's formalism of classical mechanics by a totally different mathematical scheme, whose physical interpretation has remained a matter of controversy to the present day (Jammer 1974).

Quantum mechanics has many strange features, all of which appear to be related (including non-locality, another holistic property called entanglement, as well as the phenomenon described as Schrödinger's Cat). What counts for our purpose is that its predictions are a priori probabilistic: instead of specifying one particular outcome of some physical process with certainty, as classical physics does (at least under ideal circumstances and for an ideal calculator such as Laplace's demon), quantum mechanics merely states a range of possible outcomes, even though each probability can be precisely predetermined. Indeed, quantum mechanics allows for the possibility of an absolutely random coin flip, realized, for example, by a single photon (that is, the basic quantum of light), which may or may not be transmitted by a polarizer, or by a spin measurement on an electron. Such quantum-mechanical coin flip devices are even commercially available from the Swiss company ID Quantique, which "commercializes a quantum random number generator, which is the reference in the gaming and lottery industries" (ID Quantique 2015). With this "random number generator," we return to several earlier themes, the casus, hazard, and the Wheel of Fortune, but now at the most basic level of matter, at which Laplace's demon expected to find nothing but predictable order.

The probabilistic interpretation of quantum mechanics had been in the air almost from the beginning, and notably, à contre-coeur, in the work of Einstein himself, but it was first explicitly proposed (and declared to be fundamental) in a paper by Born in 1926 on collision theory. This paper also provided a formula for the probabilities of the various outcomes, which is now known as "Born's Rule" and which forms the basis of practically all quantitative - and extremely successfulpredictions of quantum theory. What is crucial in the present context is that Born's probabilistic interpretation of quantum physics was construed by him and his 
colleagues in terms of a turn to indeterminism. The latter idea was reinforced by Heisenberg's famous paper of 1927, which proposed the uncertainty relations now named after him. Heisenberg suggested that quantum mechanics was not only indeterministic in its inability to predict the outcome of a single experiment, but also in its failure to specify initial conditions with arbitrary accuracy (see Mehra and Rechenberg 2000 and 2001 for a historical overview of this episode). In the wake of Born's and Heisenberg's epoch-making papers, Niels Bohr (backed by most if not all of the other leading players except Einstein and Schrödinger) soon stepped forward as the champion of indeterminism, a position which, with the assistance of Heisenberg and Pauli, he successfully defended against Einstein's penetrating and relentless criticism during their famous debate from 1927 to 1949 (Bohr 1949).

The general perception among physicists is that Bohr emerged victorious from this debate with Einstein, and that determinism and hence the epistemic view of probability is a thing of the past, at least in fundamental physics, forever replaced by the indeterminism of quantum mechanics. Whether this view is really correct remains to be seen, however. It certainly cannot be proved mathematically that quantum mechanics, even if it should be the correct and ultimate theory of nature, implies indeterminism; acceptable models to the contrary exist (such as Bohmian mechanics). Furthermore, one should be open-minded to possible modifications of quantum mechanics, including underlying theories that would restore determinism, whilst reproducing its probabilistic predictions by averaging over so-called hidden variables. The nature of contemporary discussions is to put constraints on deterministic interpretations of quantum mechanics and on possible refinements thereof, as first attempted by von Neumann in 1932 and more successfully in John Stuart Bell's path-breaking work of 1964. Such constraints typically make such alternative theories unattractive, but not impossible. However, the discussion is ongoing, and the last word clearly hasn't been spoken yet.

With this mention of contemporary discussions in fundamental physics, our selective survey of almost 2500 years of philosophical and scientific reflections on chance, coincidence, fortune, randomness, luck and related concepts comes to a close. Does it tell us anything helpful? Maybe above all this, that in specific domains such as statistics, evolutionary biology, or quantum physics, the last three hundred years have generated specific technical sub-meanings of several of these terms. At the same time, it is also striking that none of the discussions seems to have come to a close. We have seen, for example, how the deterministic world-view of the ancient atomists was supplanted by Aristotelianism, which identified the atomists" "blind necessity" as "mere chance," rejecting it; how Christian philosophy tried to find degrees of freedom within a cosmos otherwise defined by an omnipotent, providential God, who was however not to be held responsible for everything, including evil, that occurred in it; how in the Newtonian age a scientific determinism returned to prominence, which was sometimes accompanied by an overt rejection of any divine agency; how this deterministic worldview was shattered by a quantum physics that seemed to locate indeterminacy, probabilistic and random behaviour at the lowest material and energetic levels and in the very laws 
that describe them; and finally how, from Einstein's protests until today, the hope of finding an intellectually more satisfactory, that is, deterministic model has never entirely vanished.

\section{A Conclusion ex negativo}

Our first, etymological, approach has taught us something about the common element of several of the words in our cluster. As our eyes are usually directed ahead of us, a falling object will tend to surprise us. We stop, in shock or pleasantly surprised, to contemplate the unexpected arrival. Such a situational and emotional description of our cluster of concepts - inspired as it was by the verb "falling" that underlies casus, "coincidence," "accident" as well as a number of words related to the falling of dice-will, however, only take us so far. In specific situations, such as when we receive a random assignment or try to calculate our chances of winning in the lottery, the archetypal situation of the falling object will seem quite remote. Moreover, we have seen that languages don't divide the words along similar lines. No English or French word is as broad as the German Zufall, and what has a neutral meaning in one language, such as the French hazard or the Latin accidens, has negative connotations in another.

Our second, main approach has been begriffsgeschichtlich. We don't need to repeat the conclusions of that section once more. Suffice it to say here that Hegel would be dismayed: we have not been able to detect any dialectical progress from the ancient Greeks up to today's physicists in the way in which scientists and philosophers resolved the perennial tension between the predictable and the unpredictable; between the necessary and the contingent; between necessity and chance; or to dismiss fate, fortune, the accidental and the random. Given the developments in evolutionary biology and quantum physics of the past 150 years, it seems rather as if "chance," "randomness," and "coincidence" had been restored to a place of respectability that they had previously lost. Indeed, whether our personal surprise at a given event is merely a sign of personal ignorance or is instead a necessary feature of this universe has once again been elevated to the status of unresolved question.

One thing is certain. Time and again, throughout our pages, it has become evident that any of the words with which we have been engaged could only be understood if we also understood the type of explanation that it attempted to exclude. And precisely because the alternative did not have a stable identity, it was obvious that its anti-pole also had to change meaning. In the course of our chapter, we have found the word "chance" opposed to "fate," "purpose," "providence," "natural laws," "determinism," or simply to "the knowledge of causes." Given this heterogeneous list, it is evident that the common opposite, "chance," was doomed to be a slippery concept.

The helpfulness of understanding our words ex negativo, that is, from their respective contraries, should be evident. It helps understand, for example, the 
conceptual clash between the ancient atomists and Aristotle. As we recall, Democritus and Leucippus had proposed that the world had come about by necessity, through a blind and mechanical process of atomic combination, because "nothing exists at random." But what they regarded as "necessity" was in Aristotle's terminology mere "chance," because the atomists' cosmogony took place without any plan or purpose. Or take the disagreements over whether divine providence allowed for any fortuitous events. If "chance" is taken to mean that something happened without divine foreknowledge, as Cicero postulated, providentialism is indeed incompatible with it. If "chance" means, by contrast, that "something other than was intended happens on account of other reason," as Boethius argued, then it is compatible with providentialism in the precise sense that the intentions in question are ours, not God's. Or, again, take the conflict between Leibniz and Clarke over whether "a will without reason" amounts to "the chance of the Epicureans" (Leibniz), or whether instead an act of will per definition excludes the "blind necessity of fate" (Clarke). Similarly, when Hugo Boxel objected that necessity was the contrary of freedom, not of chance, as Spinoza had assumed, the latter remarked on "the difficulties experienced by two people following different principles, and trying to agree on a matter." Finally, take the redefinition of "chance" in the early modern period, in which someone like David Hume could claim that there is "no such thing as Chance in the world" (Chance written with a capital ' $C$ '), adding that in a probabilistic sense, one was justified in speaking of "chances," written with a lower cap.

It is often mockingly asserted that philosophy is that academic discipline that deals with questions that have no answers, or, more maliciously, that the reason why philosophers can still engage with two thousand year-old texts is because there has been no philosophical progress in all those centuries. If there should be any truth to this view, it must with equal right be applied to the philosophical aspects of all modern sciences (those grown-up daughters of what up to the seventeenth century was "natural philosophy"). After all, we have seen, maybe with surprise, how in each moment of scientific reflection on the relationship between natural causality, determinacy, and chance, the ancient Greek vocabulary tends to re-emerge. What has been overly evident in C. S. Peirce's decision to re-introduce a Greek term (namely tuchê) for a philosophy based on "chance" is true more generally. The "fortune" of our cluster of words has indeed followed the logic of the Wheel of Fortune: tuchê, "chance," or "randomness," temporarily deposed and "without kingdom," have returned to the top of the wheel, to rule.

In a book dealing with ancient Greek concepts of nature, the famous physicist Erwin Schrödinger once wrote:

By the laws of physics we are forced in each moment to do whatever we do. What is the point then in considering whether it is right or wrong? Where is there any room for a moral law, if the omnipotent law of nature does not provide it with a chance to speak? Today, the antinomy is as unresolved as it was twenty-three centuries ago (Schrödinger 1956, 18). 
Open Access This chapter is distributed under the terms of the Creative Commons Attribution-Noncommercial 2.5 License (http://creativecommons.org/licenses/by-nc/2.5/) which permits any noncommercial use, distribution, and reproduction in any medium, provided the original author(s) and source are credited. The images or other third party material in this chapter are included in the work's Creative Commons license, unless indicated otherwise in the credit line; if such material is not included in the work's Creative Commons license and the respective action is not permitted by statutory regulation, users will need to obtain permission from the license holder to duplicate, adapt or reproduce the material.

\section{References}

Alexander, H. G. (Ed.). (1956). The Leibniz-Clarke correspondence. Together with extracts from Newton's Principia and Opticks. Manchester: Manchester University Press.

Aristotle (1933). Metaphysics (H. Tredennick, Trans.) (Loeb Edition, 2 Vols.). London and Cambridge, MA: Harvard University Press.

Aristotle (1935). Athenian constitution. Eudemian ethics. Virtues and vices (H. Rackham, Trans.) (Loeb Edition). London and Cambridge, MA: Harvard University Press.

Aristotle (1937). Parts of animals. Movement of animals. Progression of animals (A. L. Peck, Trans.) (Loeb Edition). London and Cambridge, MA: Harvard University Press.

Aristotle (1957). Physics (P. H. Wicksteed \& F. M. Cornford, Trans.) (Loeb Edition, 2 Vols.). London and Cambridge, MA: Harvard University Press.

Augustine (1841). Quaestionum in Heptateuchum libri VII. In Sancti Augustini ... Opera omnia... Vol. 3, pt. 1 (= Patrologia Latina, Ed. J. P. Migne, Vol. 34, pp. 547-824). Paris: Migne.

Augustine (1998). The city of God against the Pagans (R. W. Dyson, Ed., Trans.) (Cambridge Texts in the History of Political Thought). Cambridge: Cambridge University Press.

Bobzien, S. (1998). Determinism and freedom in Stoic philosophy. Oxford: Clarendon Press.

Bobzien, S. (2000). Did Epicurus discover the free-will problem? Oxford Studies in Ancient Philosophy, 19, 287-337.

Boethius, A. (1897). The consolation of philosophy (H. R. James, Trans.). Oxford: Oxford University Press.

Boethius, A. (2000). The consolation of philosophy (V. Watts, Trans.). London: Hamish Hamilton.

Boethius, A. (1891). In librum De interpretatione editio secunda. In J. P. Migne (Ed.), Patrologia Latina (Vol. 64). Paris: Migne.

Bohr, N. (1949). Discussion with Einstein on epistemological problems in atomic physics. In P. A. Schilpp (Ed.), Albert Einstein: Philosopher-scientist (pp. 201-241). La Salle: Open Court.

Boyle, R. (2000a). Considerations about the excellency and grounds of the mechanical hypothesis [1674]. In M. Hunter \& E. B. Davis (Eds.), The works of Robert Boyle (Vol. 8, pp. 104-105). London: Pickering \& Chatto.

Boyle, R. (2000b). Free enquiry into the vulgarly received notion of nature [1686]. In M. Hunter \& E. B. Davis (Eds.), The works of Robert Boyle (Vol. 10, pp. 99-116). London: Pickering \& Chatto.

Brush, S. (1976). The kind of motion that we call heat. Amsterdam: North-Holland.

Byrne, E. F. (1968). Probability and opinion. The Hague: Cadell.

Carmina burana: die Lieder der Benediktbeurer Handschrift (1979) (B. Bischoff, H. Hilka, O. Schumann, C. Fischer, H. Kuhn, G. Bernt, Ed., Trans.). Munich: Deutscher Taschenbuch Verlag.

Cherniss, H. F. (1935). Aristotle's criticism of Presocratic philosophy. Baltimore: Johns Hopkins Press.

Cicero (1923). On old age. On friendship. On divination (W. A. Falconer, Trans.) (Loeb Classical Library). London and Cambridge, MA: Harvard University Press. 
Cicero (1941). On the orator: Book 3. On fate. Stoic paradoxes. Divisions of oratory (H. Rackham, Trans.) (Loeb Classical Library). London and Cambridge, MA: Harvard University Press.

Darwin, Ch. (1859). On the origin of species by means of natural selection; or the preservation of favoured races in the struggle for life. London: John Murray.

Daston, L. (1988). Classical Probability in the Enlightenment. Princeton: Princeton University Press.

Duden. Deutsches Universalwörterbuch (2007) (6th ed.). Mannheim, Leipzig, Vienna, Zurich: Dudenverlag.

Dudley, J. (2012). Aristotle's concept of chance: Accidents, cause, necessity, and determinism. Albany: SUNY Press.

Edmunds, L. (1972). Necessity, chance, and freedom in the early atomists. The Phoenix, 26, 342357.

Epicurus (1926). The extant remains (C. B. Bailey, Ed., Trans.). Oxford: Clarendon Press.

Epicurus (1931). Letter to Herodotus, Letter to Pythocles, Letter to Menoeceus, Principal sayings = vol. 2 of Diogenes Laertius: Lives of Eminent Philosophers (2 Vols.) (R. D. Hicks, Ed.) (Loeb Edition). London and Cambridge, MA: Havard University Press.

Fowler, D. (1983). Lucretius on the Clinamen and 'Free Will' (II 251-93). SYZÊTESSIS: Studi sull'epicureismo greco e romano offerti a Marcello Gigante (pp. 329-352.). Naples: Centro internazionale per lo studio dei papiri ercolanesi.

Furley, D. J. (1967). Two studies in the Greek atomists. Princeton: Princeton University Press.

Gassendi, P. (1658). Opera omnia (6 Vols.). Lyon: Laurent Anisson et Jean-Baptiste Devenet.

Hacking, I. (1975). The emergence of probability: A philosophical study of early ideas about probability, induction and statistical inference. Cambridge: Cambridge University Press.

Hacking, I. (1983). Nineteenth century cracks in the concept of determinism. Journal of the History of Ideas, 44, 455-75.

Henry, J. (2009). Voluntarist theology at the origins of modern science: A response to Peter Harrison. History of Science, 47, 79-113.

Historisches Wörterbuch der Philosophie (1971-2007) (13 Vols.) (J. Ritter, K. Gründer \& G. Gabriel, Eds.). Basel: Schwabe AG.

Hume, D. (1748). An enquiry concerning human understanding. London: A. Millar.

Hume, D. (1779). Dialogues concerning natural religions (2nd ed.). London: s.n.

Hume, D. (2007). A treatise of human nature (Clarendon Edition). Oxford: Oxford University Press.

ID Quantique (2015). Retrieved on June 12, 2015 http://www.idquantique.com.

Jammer, M. (1966). The conceptual development of quantum mechanics. New York: McGraw-Hill.

Jammer, M. (1974). The philosophy of quantum mechanics: The interpretations of quantum mechanics in historical perspective. New York: McGraw-Hill.

John Buridan (1509). Subtilissimae questiones super octo libros Aristotelis. Paris: Denis Roce.

Kirk, G. S., Raven, J. E., \& Schofield, M. (1983). The Presocratic philosophers. A critical history with a selection of texts (2nd ed.). Cambridge: Cambridge University Press.

Kretzmann, N. (1999). The metaphysics of creation: Aquinas' natural theology in 'Summa contra gentiles' II. Oxford: Clarendon Press.

Laertius, D. (1925). Lives of eminent philosophers (2 Vols.) (R. D. Hicks, Trans.) (Loeb Edition). London and Cambridge, MA: Harvard University Press.

La Mettrie, J.O. de (1764). L'homme machine. In Oeuvres philosophiques (Vol. 1). Amsterdam: s.n.

Laplace, P.-S. (1902). A philosophical essay on probabilities (6th ed.) (F. W. Truscott \& F. L. Emory, Trans.). New York: Wiley.

Laplace, P.-S. (1812). Théorie analytique des probabilités. Paris: Mme. Ve. Courcier.

Lawrence, S. (2013). Fate and Chance. In H. M. Roisman, (Ed.), The encyclopedia of Greek tragedy (pp. 502-506). London: Wiley.

Lewis, C. S. (1964). Poems (W. Hooper, Ed.). London: Harcourt.

Lewis, C. T., \& Short, Ch. (1879). A Latin dictionary. New York: Wiley. 
Long, A. A. (1977). Chance and natural law in Epicureanism. Phronesis, 22, 63-88.

Lucretius (1924). On the nature of things. (W. H. D. Rouse, Trans.revised by M. F. Smith) (Loeb Edition). London and Cambridge, MA: Harvard University Press.

Lucretius (1947). Titi Lucreti Cari De rerum natura libri sex (3 Vols.) (C. B. Bailey, Ed. Trans.). Oxford: Clarendon Press.

Lüthy, C. H. (2003). The invention of atomist iconography. In W. Lefèvre, J. Renn \& U. Schoepflin (Eds.), The power of images in early modern science (pp. 117-138). Basel/Boston/Berlin: Birkhäuser.

Maier, Anneliese. (1949). Notwendigkeit, Kontingenz und Zufall. In Maier, Die Vorläufer Galileis im 14. Jahrhundert (pp. 219-250). Rome: Edizioni di Storia e Letteratura.

Maupertuis, P. L. M. de (1752). Essai de cosmologie. In Oeuvres (4 Vols.) (Vol. 1, pp. 1-58). Lyon: J.M. Bruyset.

Mehra, J., \& Rechenberg, H. (2000, 2001). The Historical Development of Quantum Theory. Vol. 6: The Completion of Quantum Mechanics 1926-1941. Part 1: The Probabilistic Interpretation and the Empirical and Mathematical Foundation of Quantum Mechanics, 1926-1936. Part 2: The Conceptual Completion of Quantum Mechanics. New York: Springer.

O'Keefe, T. (2005). Epicurus on freedom. Cambridge: Cambridge University Press.

Online Etymological Dictionary. (2015). Retrieved on May 15-20, 2015 http://www.etymonline. com.

Osler, M. J. (1994). Divine will and the mechanical philosophy: Gassendi and Descartes on contingency and necessity in the created world. Cambridge: Cambridge University Press.

Oxford English Dictionary (1989). (2nd ed.). Oxford: Oxford University Press.

Pacuvius (1897). Scaenicae Romanorum poesis fragmenta (O. Ribbeck, Ed.) (3rd ed.). Leipzig: Teubner.

Peirce, C. S. (1892). The doctrine of necessity examined. The Monist, 2, 321-37.

Peter Abelard (1919). In B. Geyer (Ed.), Peter Abaelards philosophische Schriften. I. Die Logica 'Ingredientibus' (pp. 1-109). Münster: Verlag der Aschendorffschen Verlagsbuchhandlung.

Plutarch (1976). Moralia. Vol. 13, pt. 2: Stoic Essays (H. Cherniss, Trans.) (Loeb Classical Library). London and Cambridge, MA: Harvard University Press.

Purinton, J. S. (1999). Epicurus on 'free volition' and the atomic swerve. Phronesis, 44, 253-99.

Roger Bacon (1935). Quaestiones super libros VIII physicorum Aristotelis [ca. 1250] (R. Steele, Ed.), in Bacon, Opera hactenus inedita (vol. 13). Oxford: Oxford University Press.

Sarasohn, L. T. (1985). Motion and morality: Pierre Gassendi, Thomas Hobbes and the mechanical world-view. Journal of the History of Ideas, 46, 363-79.

Sedley, D. (1988). Epicurean anti-reductionism. In J. Barnes \& M. Mignucci (Ed.), Matter and metaphysics (pp. 295-327). Naples: Bibliopolis.

Sklar, L. (2009). Philosophy of statistical mechanics. The Stanford encyclopedia of philosophy (Summer 2009 Edition) (E. N. Zalta, Ed.). Retrieved on May 15, 2015 http://plato.stanford. edu/archives/sum2009/entries/statphys-statmech/.

Spinoza, B. de (1883). The chief works of Benedict de Spinoza. On the improvement of the understanding. The ethics. Corresponedence (R.H.M. Elwes, Trans. \& Intro.). London: Bell.

Stachel, J. (Ed.) (1998). Einstein's miraculous year. Five papers that changed the face of physics. Princeton: Princeton University Press.

Thomas Aquinas (1964-1976). Summa theologiae (60 Vols.). Cambridge: Blackfriars.

Thomas Aquinas (1975a). Summa contra gentiles (J. F. Anderson, Ed., Trans.). Book 2: Creation. Notre Dame: University of Notre Dame Press.

Thomas Aquinas (1975b). Summa contra gentiles (V. J. Bourke, Ed., Trans.). Book 3: Providence. Notre Dame: University of Notre Dame Press.

Uffink, J. (2007). Compendium to the foundations of classical statistical mechanics, in Butterfield, J. \& Earman, J. (Eds.), Handbook for the philosophy of physics (pp. 924-1074). Amsterdam: North Holland/Elzevier. 
Uffink, J. (2014). Boltzmann's work in statistical physics, in E. N. Zalta (Ed.), The Stanford Encyclopedia of Philosophy (Fall 2014 Edition). Retrieved on May 15, 2015 http://plato. stanford.edu/archives/fall2014/entries/statphys-Boltzmann/.

Vogt, P. (2011). Kontingenz und Zufall. Eine Ideen- und Begriffsgeschichte. Berlin: Akademie Verlag.

Vollmer, M. (2009). Fortuna Diagrammatica. Das Rad der Fortuna als bildhafte Verschlüsselung der Schrift De Consolatione Philosophiae des Boethius. Frankfurt: Peter Lang.

Voltaire (1766). Le Philosophe ignorant. S.1., s.n.

Voltaire (1901). The philosophical dictionary (W. F. Fleming, Trans.). 5 vols. = The Works of Voltaire. A Contemporary Version (J. Morley, T. Smollett, W. F. Fleming, Eds. \& Trans.) (Vols. 3-7). New York: E. R. DuMont. 